\title{
Ancient Irrigation and Buddhist History in Central India: Optically Stimulated Luminescence Dates and Pollen Sequences from the Sanchi Dams
}

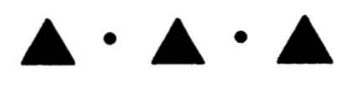

\author{
JULIA SHAW, JOHN SUTCLIFFE, LINDSAY LLOYD-SMITH, \\ JEAN-LUC SCHWENNINGER, AND M. S. CHAUHAN \\ (with contributions by O. P. Misra and Emma Harvey)
}

THIS ESSAY PRESENTS THE RESULTS OF a recent pilot project aimed at obtaining optically stimulated luminescence (OSL) dates from a group of ancient irrigation dams in central India. ${ }^{1}$ These dams were initially documented between 1998 and 2002 during a multiphase exploration project carried out over $750 \mathrm{~km}^{2}$ around Sanchi (Figs. 1 and 2), a well-known Buddhist site in Madhya Pradesh recently accredited with a UNESCO World Heritage status (Shaw 2000, 2004a, 2004b, 2005, forthcoming; Shaw and Sutcliffe 2001, 2003a, 2003b, 2005). The Sanchi Survey was aimed at relating the site's Buddhist monuments to their wider archaeological landscape, resulting in the systematic recording of 35 additional Buddhist sites, 145 habitational settlements, over 1000 sculptures, numerous painted rock shelters, and the 16 dams discussed here. These data have provided an empirical basis for building an integrated model of religious and economic change in ancient India, assessing how Buddhism established itself in new areas, and relating its spread to other key processes such as urbanization, state formation, religious change, and the development of new agrarian systems.

A number of hypotheses relating specifically to the dams have been presented in earlier papers, based on surface remains and present-day hydrological and climate data (Shaw and Sutcliffe 2001, 2003a, 2003b). These can be summarized as follows: (1) The earliest phase of dam construction occurred approximately between the third and first centuries B.C., in keeping with the main building phases at Sanchi and neighboring Buddhist sites; (2) they were built to provide irrigation, probably for rice, as a response to the increased population levels suggested by the

Julia Shaw is a lecturer in South Asian archaeology at the Institute of Archaeology, University College London. John Sutcliffe is a hydrological consultant based in Reading, UK. Lindsay Lloyd-Smith is a Ph.D. candidate in the Department of Archaeology, University of Cambridge. Jean-Luc Schwenninger is a research fellow in luminescence dating, Research Laboratory for Archaeology and the History of Art, Oxford, UK. M. S. Chauhan is a scientist of Quaternary palynology at the Birbal Sahni Institute of Palaeobotany, Lucknow, in Uttar Pradesh, India. 


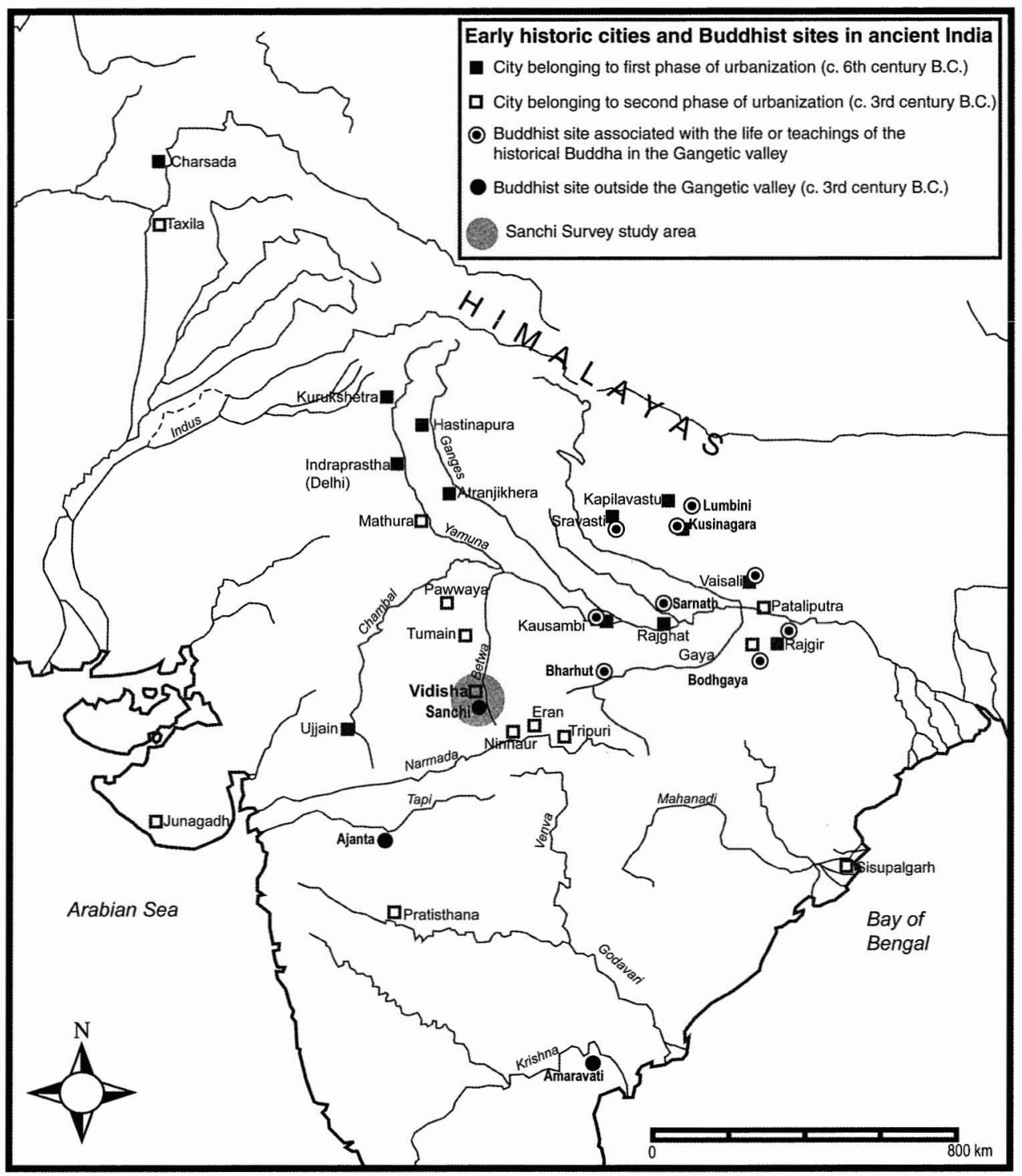

Fig. 1. Sites mentioned in the text.

distribution of habitational and Buddhist sites in Vidisha's hinterland; (3) they were part of a cultural package that accompanied the spread of Buddhism, urbanization, and the development of centralized state polities in the late centuries B.C.; and (4) they were central to the development of sustainable exchange networks between Buddhist monks and the local laity, just as early irrigation systems in Sri Lanka formed the basis of monastic landlordism from the second century B.C. onward (Gunawardana 1971).

Recent attempts to develop and assess these hypotheses have included satellite remote sensing and intensive Total Station and GPS site mapping (Shaw forth- 


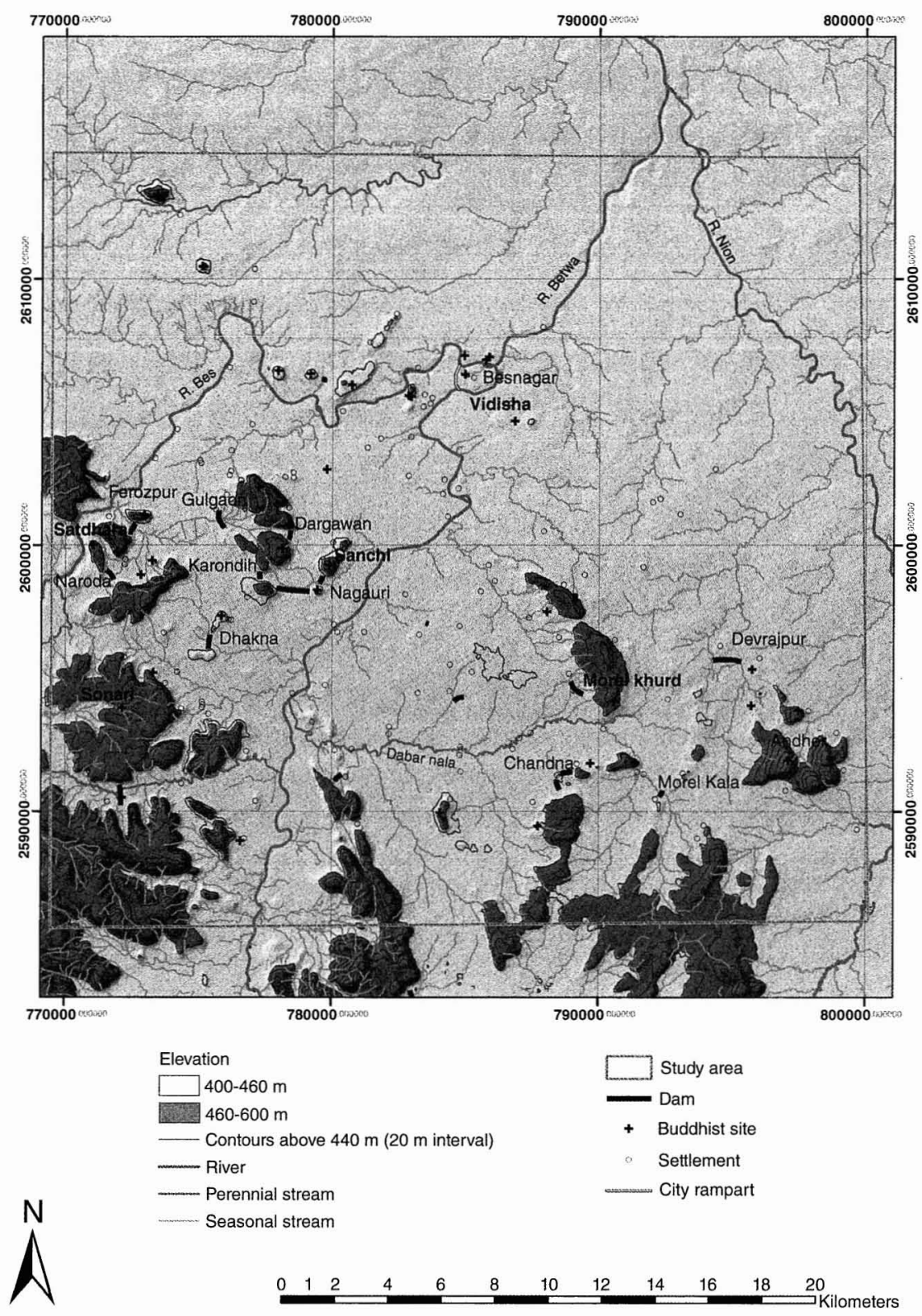

Fig. 2. The Sanchi Survey area showing distribution of dams and other archaeological sites.

coming; Beck and Shaw forthcoming; Shaw and Sutcliffe 2005) and the geological dating and pollen analysis that formed the focus of the current pilot project. ${ }^{2}$ The latter focused on two major dam sites: Sanchi, in the center of the study area, and Devrajpur, around $14 \mathrm{~km}$ to the east (see Fig. 2). ${ }^{3}$ Existing road cuttings were scraped back to reveal dam sections that cast new light on aspects of dam construction and allowed for the collection of sediments and ceramics for OSL 
dating. Sediment samples were also collected from cores hand drilled in the driedup reservoir beds for supplementary OSL dating and pollen analysis. The results of the latter provided useful insights into land use, but they are only described in summary form here; more detailed descriptions will follow elsewhere (Shaw and Chauhan forthcoming). This essay is primarily concerned with the first component of the project, which confirmed the suitability of local sediments for OSL and TL dating methods (an important consideration before designing a longer-term program of research), as well as affirming our working hypothesis that the dams were constructed-along with the earliest Buddhist monuments in central India-in the late centuries B.C. (Shaw and Sutcliffe 2001, 2003a, 2003b, 2005). ${ }^{4}$

\section{THE SANCHI SURVEY: BACKGROUND TO RESEARCH}

\section{Buddhist Archaeology, Urbanization, and the State}

Sanchi is one of India's best preserved and most studied Buddhist sites, with a continuous constructional sequence from c. third century B.C. to twelfth century A.D. (Marshall et al. 1940; Willis 2000). Its earliest history was closely connected with the Mauryan Empire, whose westward spread from its epicenter in the Gangetic valley was responsible in part for Buddhism's transformation from a regional cult into a pan-Indian and subsequently pan-Asian phenomenon. Notwithstanding ongoing disagreements over the dating of the historical Buddha (Bechert 1991), his life and teachings are usually placed sometime between the sixth and fifth centuries B.C. There is a distinct absence of "Buddhist archaeology" relating to this period (Coningham 2001), although the major cities mentioned in texts purporting to have been composed during the Buddha's lifetime (e.g, Rajgir, Kausambi, Sravasti, Vaisali) have been identified archaeologically and belong to India's first phase of early historic urbanization (see Fig. 1). It is somewhat later, following the Mauryan emperor Aśoka's (r. 273-236 в.C.) conversion to heterodoxy, that Buddhism first appears in the archaeological record, in the form of stūpas and shrines, both in the Buddhist heartland and in areas farther afield, including Sanchi. The overlapping processes of Buddhist propagation and imperial expansion can be tracked through the distribution of Aśokan edicts that extend from Afghanistan to South India (Allchin and Norman 1985); many of these, like the Aśokan pillar at Sanchi, stand within Buddhist compounds. This is also when urban culture-already prevalent in the Gangetic valley for several centuriesspreads westward, as attested by the archaeological sequence at Vidisha, about 8 $\mathrm{km}$ to the north of Sanchi, and other central Indian city sites such as Eran, Tumain, and Pawwaya (see Fig. 1).

Although these three processes were evidently linked, there are considerable problems, some of which the Sanchi Survey sought to address, in defining the nature of this relationship. These include the lack of horizontal excavation at Vidisha and other early historic city sites and the traditional site-based focus of South Asian archaeology, which rarely looks beyond individual sites to patterns in the wider archaeological landscape. ${ }^{5}$ Further problems stem from outdated models of state in ancient India based on the assumption that the distribution of Aśokan edicts represents the boundaries of a unified political entity. ${ }^{6}$ 


\section{Buddhist Propagation and Patronage}

Whatever the role of the state in the initial establishment of Buddhism in central India, it was only in the post-Mauryan period (c. second to first century B.C.) that Buddhism really took root in the social and religious landscape, as demonstrated by archaeological and epigraphical evidence at Sanchi and four other previously published monastic sites: Satdhara, Sonari, Andher, and Morel khurd (Cunningham 1854; Willis 2000). These sites defined the outer boundaries of the Sanchi Survey study zone; most of the 35 monastic sites newly documented during the Sanchi Survey also belong to this second phase of Buddhist propagation (Shaw forthcoming; Shaw and Sutcliffe 2005). Inscriptions show that these prolific building campaigns were fueled not by state patronage as before but by extensive programs of collective patronage supported by powerful families and guilds (Dehejia 1992). The precise nature of this relationship is still subject to debate, the prevalent view being that it was only in the fifth century A.D., with the appearance of inscriptions recording donations of land and villages, that monks entered into direct sustainable exchange networks with local agricultural communities; and further, that the main incentive behind the generosity expressed in the earlier inscriptions was the lay acquisition of religious merit (pünya) rather than material gain (Schopen 1996). This view reflects the prevalence of a "passive" and canonical model of Buddhism that presents the ideal monk as one engaged in meditation, rather than in more material pursuits, with mendicancy being the predominant subsistence strategy.

However, as discussed elsewhere (Shaw forthcoming; Shaw and Sutcliffe 2005), although some monks no doubt continued to beg for a living, the scale and number of post-Mauryan monastic centers in the Sanchi area predicate a more integrated, sustainable system of exchange between monks and local agriculturalists (Shaw and Sutcliffe 2005; cf. Bailey and Mabbett 2003:70-72). Further, the distribution of monasteries and settlements in the area suggests a significant increase in population during the early historic period that would have exerted pressure on local resources (Shaw forthcoming). The Sanchi dams that may have been in part a response to these changes would have been senseless without a developed administrative framework for overseeing their use and upkeep (Shaw and Sutcliffe 2003a, 2005). Insights into the nature of their administration are provided by their spatial and temporal relationship to monasteries and settlements, which is remarkably similar to patterns in Sri Lanka, where epigraphical and textual evidence attests to a system of "monastic landlordism" from c. second century B.C. onward. Many of the ancient Sri Lankan dams bear inscriptions linking them to nearby monasteries whose involvement in water management was central to the development of reciprocal alliances between monks, farmers, and political elites (Gunawardana 1971; Shaw and Sutcliffe 2003a, 2005). Buddhist texts furnish additional details of this three-way web of mutual obligation, which has offered a basis for challenging the passive model of early Buddhism outlined above; the local landowner would donate an irrigation work to the sangha, which would subsequently adopt the responsibility of its management and profit control. Local farmers would then be granted access to its water supplies in exchange for a gift of a certain percentage of the resulting yields, which was then shared amongst the sangha and the original donor (Gunawardana 1979:57-59). 
The absence of epigraphical evidence at the Sanchi dams means that while it is not possible to prove the existence of similar exchange systems in central India, one may posit a more general link between the establishment of Buddhism and the construction of dams. The working hypothesis presented elsewhere (Shaw and Sutcliffe 2003a, 2005) is that Buddhism spread from eastern India as part of a wider package, including urbanization and new forms of political administration, that carried with it the need for more intensive agriculture as represented by the Sanchi dams. This hypothesis forms part of an active model of religious change indicating that monks moved into new areas with a set of motives for local communities to extend their economic support to the monastery. The view that water management was central to Buddhist propagation is supported further by observations regarding the ostentatious display of water harvesting facilities at rock-cut monasteries in western India (Shaw and Sutcliffe 2003a:92-95). It appears that the monastery's monopoly over the business of water harvesting and management was not only central to the generation of lay patronage, it also accorded directly with Buddhist theology and its preoccupation with the alleviation of suffering dukha': in a region of the world where 90 percent of the annual rainfall occurs in two to three months, it provided a very practical solution to drought and flood, two of the key causes of everyday suffering in monsoonal regions.

\section{Irrigation in Ancient India}

Scholarship on early Indian politics and economics has traditionally emphasized the role of centralized state administration in the building and management of irrigation works (Chakravarty 1998). This view rests heavily on problematically dated texts such as Kautilya's Arthaśāstra ${ }^{7}$ and from Orientalist-inspired notions regarding Asian economic systems as typified by Wittfogel's (1957) writings on "Hydraulic Civilisations of the Orient" and perpetuated by Southeast Asian ethnographers such as Clifford Geertz (1980). In Sri Lanka, the aforementioned evidence for monastery-owned irrigation works as instruments of lay patronage from the late centuries B.C. onward (Gunawardana 1971), together with ethnographic accounts of small-scale irrigation works built and managed by village councils (Leach 1959), have helped to challenge these views, as have observations regarding the priestly control of irrigation systems in Bali (Lansing 1991). Although a body of scholarship exists on the role of Hindu temple councils in the management of water supplies in medieval and premodern South India (Davison-Jenkins 1997; Morrison 1993), when it comes to ancient India, the traditional model has until recently remained unchallenged due in part to the paucity of archaeological research on specific case studies. ${ }^{8}$ The spatial and temporal relationship between dams and Buddhist sites in the Sanchi area is sufficiently close to patterns in Sri Lanka to suggest similarly devolved systems of water management based on exchange networks between landowners, farmers, and Buddhist monks (Shaw and Sutcliffe 2003a, 2005). By the Gupta period, this system appears to have been recast within a Brahmanical framework, as attested by the growing number of Hindu temples on or near the dams (Shaw forthcoming; Shaw and Sutcliffe 2005). These patterns fit with broader developments across India from the Gupta period onward, when we begin to find epigraphical evidence for Brahmanical land grants and the rise of temple-owned land and water resource structures. Although 
no such inscriptions have been found at the Sanchi dams, the most common location for the aforementioned Hindu temples is next to spillways and sluices, at the sources of water control and manipulation, and where, in other parts of South Asia, the associated donative inscription is usually located (Shaw and Sutcliffe 2003a: 78-80).

\section{The Sanchi Dams: Form and Function}

The dams in the Sanchi area are all quite similar, consisting of earthen cores with stone facing mainly on the upstream side (Fig. 3), with heights varying from 1 to $6 \mathrm{~m}$ and lengths from 80 to $1400 \mathrm{~m}$. They were constructed to a height sufficient to ensure that the reservoir volume would be closely related to the volume of runoff from the upstream catchment of each site (Shaw and Sutcliffe 2001). The reservoirs have volumes ranging between 0.03 and $4.7 \mathrm{~m}^{3} \times 10^{6}$ (i.e., 30,000 to $4,700,000 \mathrm{~m}^{3}$ ) (Shaw and Sutcliffe 2005). ${ }^{9}$ While those built on gently sloping terrain, as at Sanchi, were evidently used for upstream irrigation, dams built across deeper valleys, as found to the east of Sanchi, were probably built for downstream irrigation and are accompanied by flood-control spillways and sluices (Shaw and Sutcliffe 2005).

Chronology - Dams are difficult to date due to the nature of their construction, with building material often sourced from multiple locations and frequent repairs. Assigning an original context to associated archaeological material is rarely straightforward. The dating of Sri Lanka and South Indian dams has usually relied on inscriptions and constructional (particularly sluice) typologies (Brohier 1979

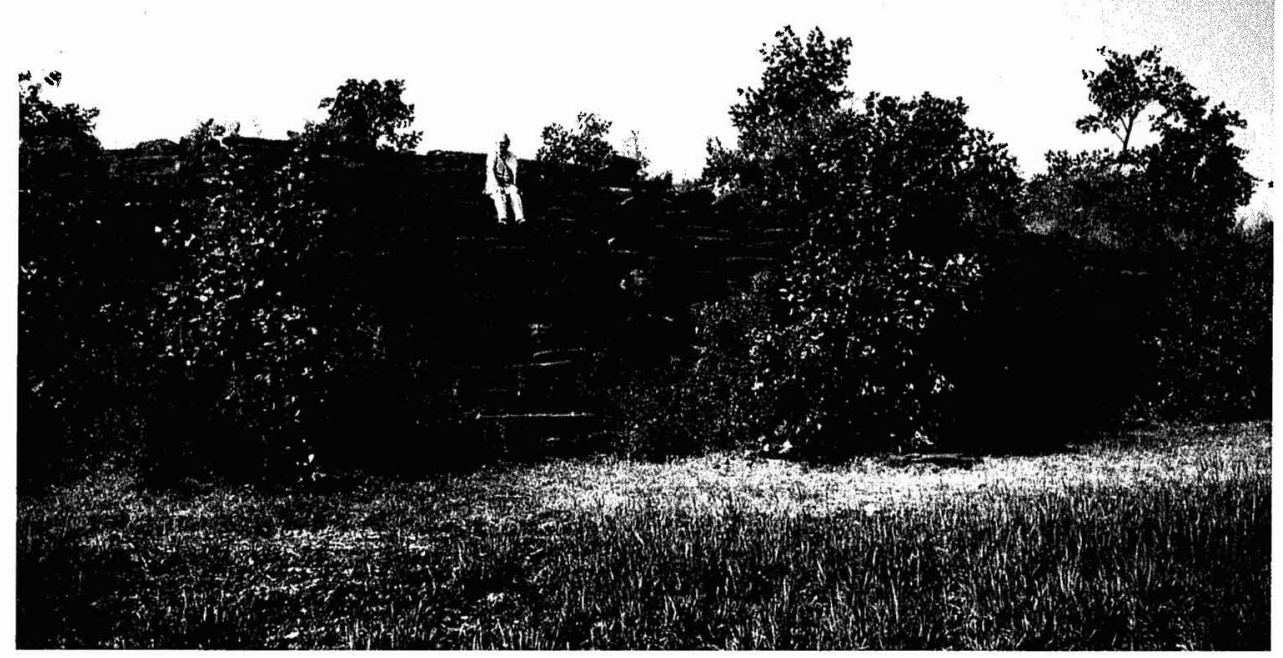

Fig. 3. Outer facing on Morel Kala dam. 
[1934]; Davison-Jenkins 1997; Parker 1909; Venkayya 1906). For the Sanchi dams, terminus ante quem dates varying between c. first century B.C. and fifth century A.D. were provided by nāga (serpent) sculptures located on or near some of the embankments (Shaw 2004a; Shaw and Sutcliffe 2001:68-71, 2003a:8485). ${ }^{10}$ Marshall (1940:13) suggested that the dam below Sanchi hill dated to $c$. third or second century B.C., in keeping with the most prolific building phases at Sanchi. This fits with the dates of associated settlements and Buddhist sites in the immediate vicinity as well as other parts of the study area, but it needs to be tested through scientific dating techniques.

In recent years, similar problems have informed the ${ }^{14} \mathrm{C}$ and OSL dating of canal systems in Sri Lanka (Myrdal-Runebjer 1994; Risberg et al. 2002) and southern Cambodia (Bishop et al. 2004:321) respectively. ${ }^{11}$ For the latter, the underlying premise was that the OSL clock was reset to zero when the sediments were last exposed to light during the original excavation or reexcavation of the canals. ${ }^{12}$ A similar assumption informed our dating of the Sanchi dams: because sediments need to be disturbed prior to being deposited in a dam, we should be able to date the last disturbance by measuring the amount of accumulated trapped charge-or time elapsed-since the sediment's last exposure to light. However, in order for the OSL dating to be successful, the sample must contain sufficient amounts of sand-sized quartz grains, and have undergone sufficient exposure to light prior to deposition in the dam. While the geology of the Sanchi area meant that the former was not a significant problem, the latter is less easy to guarantee, due to the possibility of portions of sediment remaining unexposed during the digging and redeposition process.

Successful dating is also dependent on the avoidance of light contamination during sampling. During the current pilot project, sediments were collected from dam sections using light-proof containers. Cores were also drilled in selected reservoir beds, using a hollow-headed $(0.25 \times 0.10 \mathrm{~m})$ hand auger (Fig. 4). Samples were collected from within and below the reservoir deposit using a light-resistant bag to extract sediment from the core head. Unfortunately, this is not an entirely satisfactory method and may not completely preclude light contamination.

\section{Land Use and Agricultural History}

In earlier papers (Shaw and Sutcliffe 2001, 2003a, 2005), we suggested that the water storage capacity of the Sanchi reservoirs is not necessary for the cultivation of wheat, the principal local crop today; due to the high moisture storage capacity of the local black cotton soils, wheat can be grown entirely on local rainfall, without irrigation. The total reservoir volume across the study area, based on recent revised estimates (Shaw and Sutcliffe 2005), is about $19.5 \mathrm{~m}^{3} \times 10^{6}$. With an estimated water requirement for rice of $0.8 \mathrm{~m}$, this corresponds to a total irrigated area of $24 \mathrm{~km}^{2} .{ }^{13}$ Our principal argument is that the high costs involved in constructing and maintaining the dams would have made sense if they were used for wet rice cultivation, largely because of the dramatically increased depth and intensity of irrigation. Other factors include evidence for upstream irrigation at some of the dam sites (Shaw and Sutcliffe 2005).

Current archaeobotanical research suggests that the epicenter for rice cultiva- 


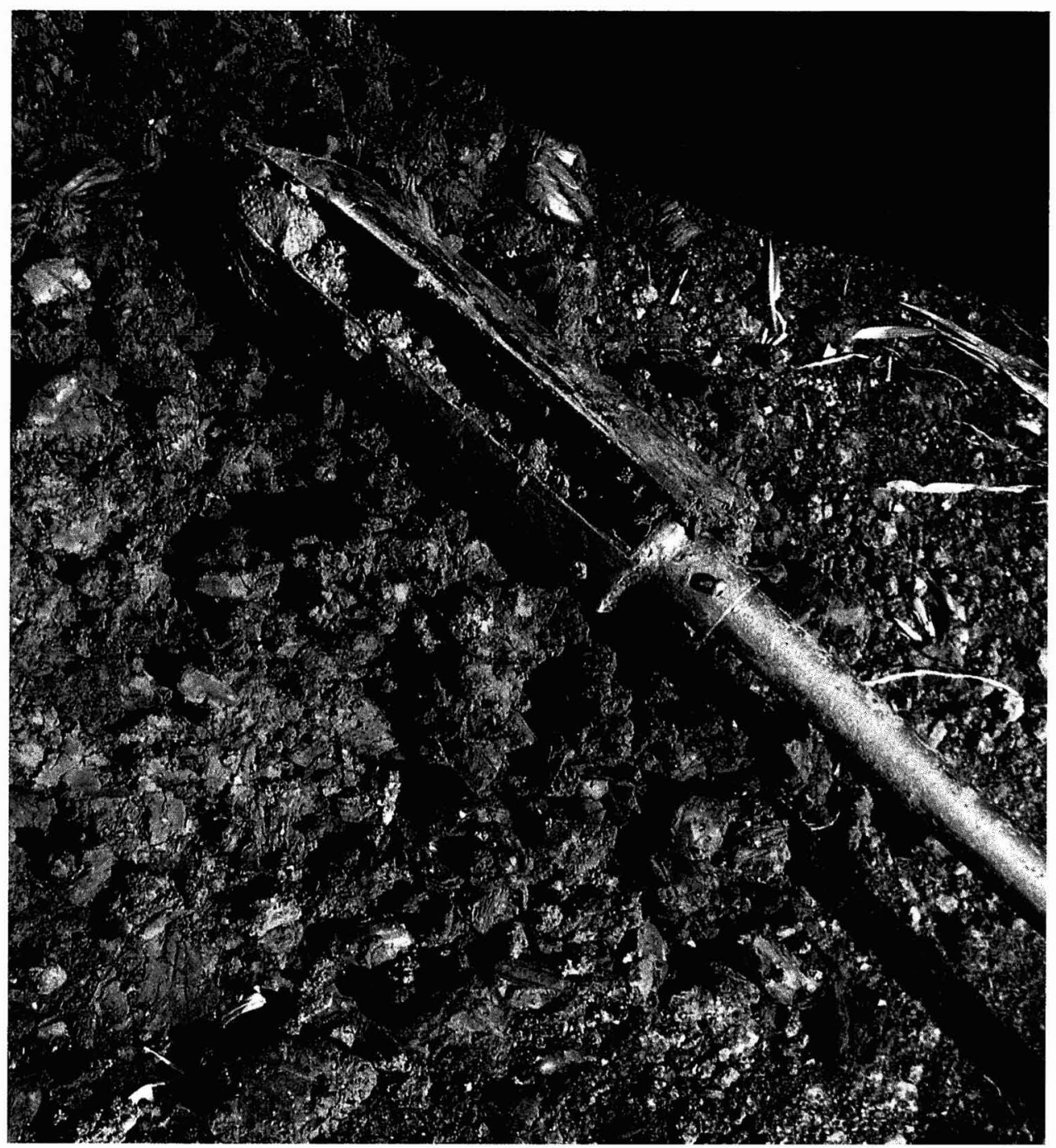

Fig. 4. Hollow-headed end of auger.

tion, from the mid-third millennium в.c., was the Gangetic valley (Fuller 2002, 2003:352). ${ }^{14}$ Limited samples from the Deccan and South India (Fuller 2002) suggest that the introduction of rice to these areas did not occur until the late centuries B.C. with the spread of Buddhism and monarchical states (Chakravarty 1998:96-97). It is likely that central India followed a similar pattern, although this has not hitherto been assessed archaeobotanically. ${ }^{15}$ Our working hypothesis (Shaw and Sutcliffe 2003a, 2005) is that the introduction of rice to central India-possibly initially as a traded commodity and later as a locally produced crop-would have been an inevitable cofactor of the westward spread of Buddhist and urban culture, both of which grew out of a predominantly rice-growing environment. ${ }^{16}$ Further, the superior yields and nutritional value of rice relative 
to irrigated wheat meant it was an effective response to increased population and economic complexity suggested by settlement and monastery distribution (Shaw and Sutcliffe 2003a).

Preliminary steps were taken during the current pilot project toward testing these hypotheses through the study of reservoir deposits for their pollen content. These analyses produced variable results, but nevertheless they offered useful insights into the advantages of such an approach over the long term. Ancient pollen sequences from central Indian lake cores have hitherto been used to reconstruct the history of woodland and grassland species, rather than agricultural crops (Chauhan 1996, 2000, 2002). This is because of the difficulties in identifying cereal types from pollen alone and also because of the problem of wind-borne spores that can travel considerable distances and thus may not reflect the immediate environment. However, even such a general profile can contain suggestive indicators of a rice-growing environment. For example, the predominance of spores from wet marshland plant species in the Sanchi sequences fits closely with the kind of waterlogged environment expected of an upstream cropping system (Shaw and Sutcliffe 2005).

By contrast, phytoliths - the nonorganic opaline silica bodies formed within and between living plant cells - can lead to the identification of individual species such as rice and wheat (Ball et al. 1993; Rosen 1992). The potential of this technique has already been demonstrated in South Asia (Eksambekar et al. 1999; Fujiwara et al. 1992; Harvey et al. 2005; Kajale and Eksambekar 2001; Madella 2003). However, identification is only reliable at the genus level, and it is difficult to distinguish between wild and domesticated rice (Harvey et al. 2005; Houyuan 1997; Madella 2003). Preliminary analysis of six samples from the Nagauri and Devrajpur reservoirs revealed a complete absence of agricultural plant phytoliths. ${ }^{17}$ This is unlikely to result from the sampling methods used; rather it confirms that agricultural plant phytoliths are more likely to survive at crop postprocessing sites and in ceramic tempers than in ancient water bodies (Emma Harvey, pers. comm.). The collection of samples from cultural deposits at settlements in the immediate vicinity of the Sanchi dams is expected to provide more precise information about local agriculture based on the identification of specific crops.

\section{THE PILOT PROJECT}

\section{The Sanchi Reservoir Complex}

Archaeological Context - The remains of a dam $350 \mathrm{~m}$ long between Sanchi hill and Nagauri to the south were originally noted by Marshall (1940:13). Standing at a height of $2.80 \mathrm{~m}$ today, this and a second embankment to the west ${ }^{18}$ would have created a reservoir covering an area of about $3 \mathrm{~km}^{2}$ with a storage capacity of about $3.6 \mathrm{~m}^{3} \times 10^{6}$, fed by streams draining from the hills to the west (Figs. 5 and 6). Two smaller tanks at Karondih and Dargawan in the short valleys between these hills appear to have been designed to maintain water levels in the main reservoir as part of an upstream irrigation system (Shaw and Sutcliffe 2005). It seems that crops (probably rice) were cultivated in the reservoir itself, with additional water being supplied from the upstream tanks as the reservoir level fell. ${ }^{19} \mathrm{~A}$ similar form of upstream irrigation was evidently practiced at other sites in the west- 


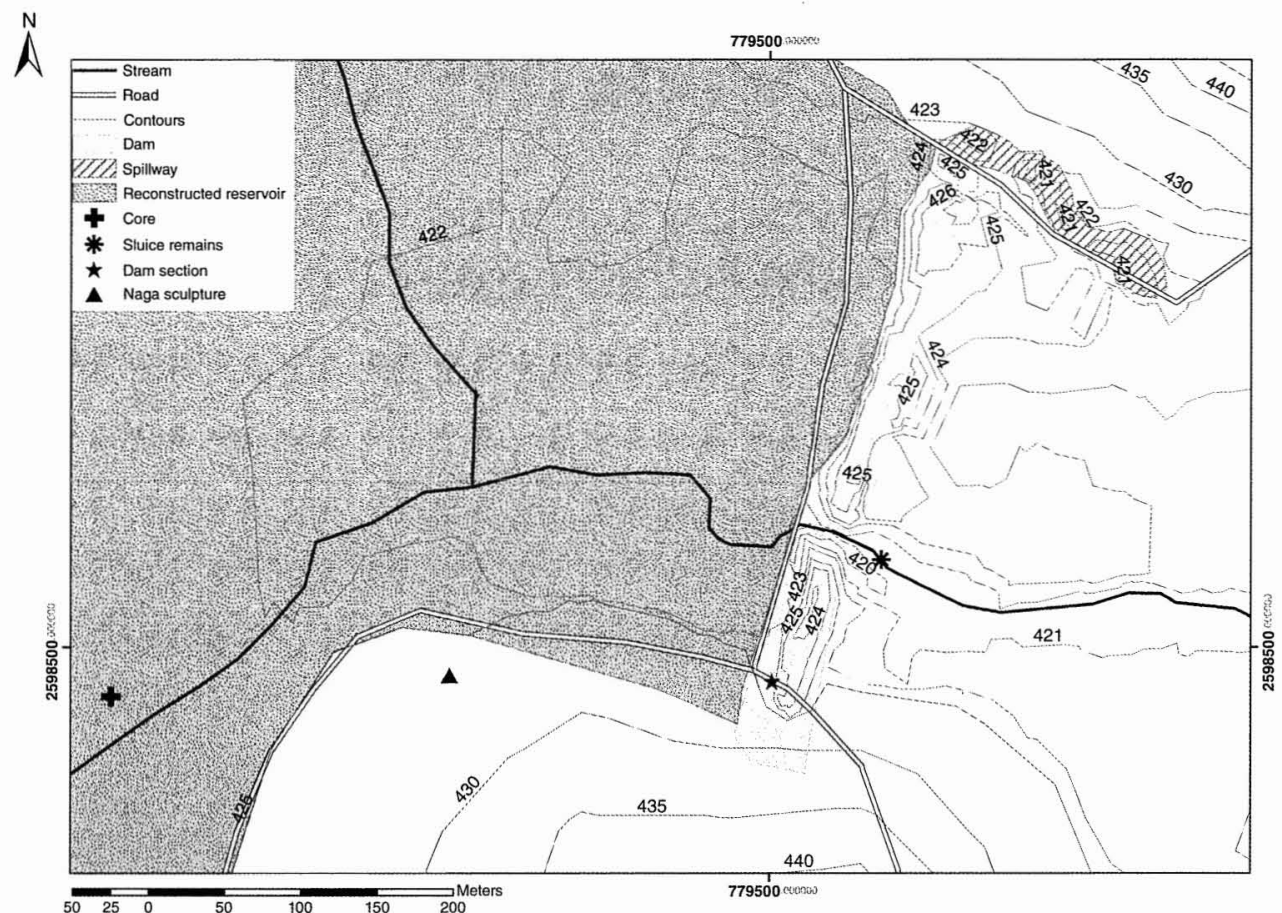

Fig. 5. Map of the Sanchi dam complex (contours generated from Total Station and satellite imagery).

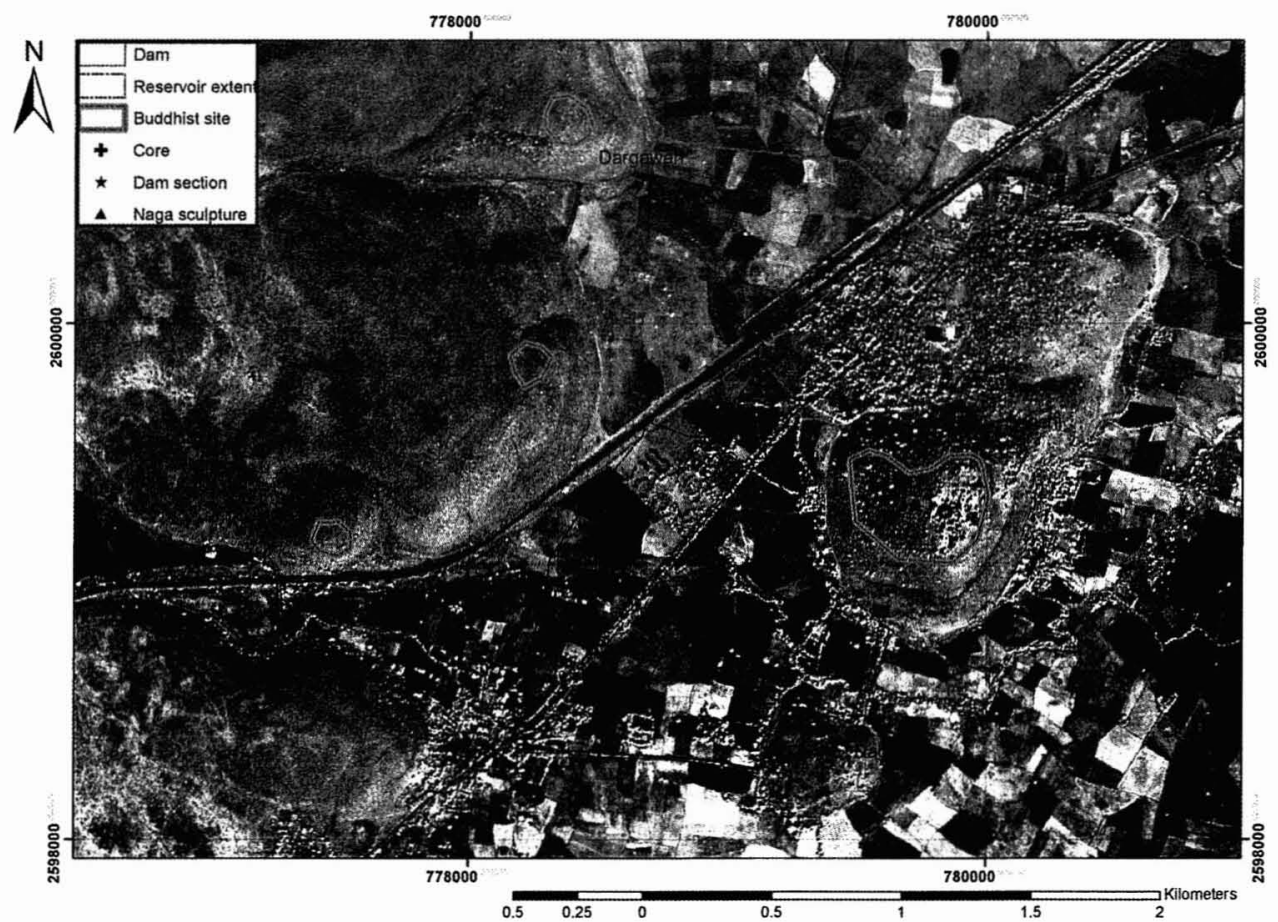

Fig. 6. Satellite (Quickbird) imagery of Sanchi reservoir complex. 


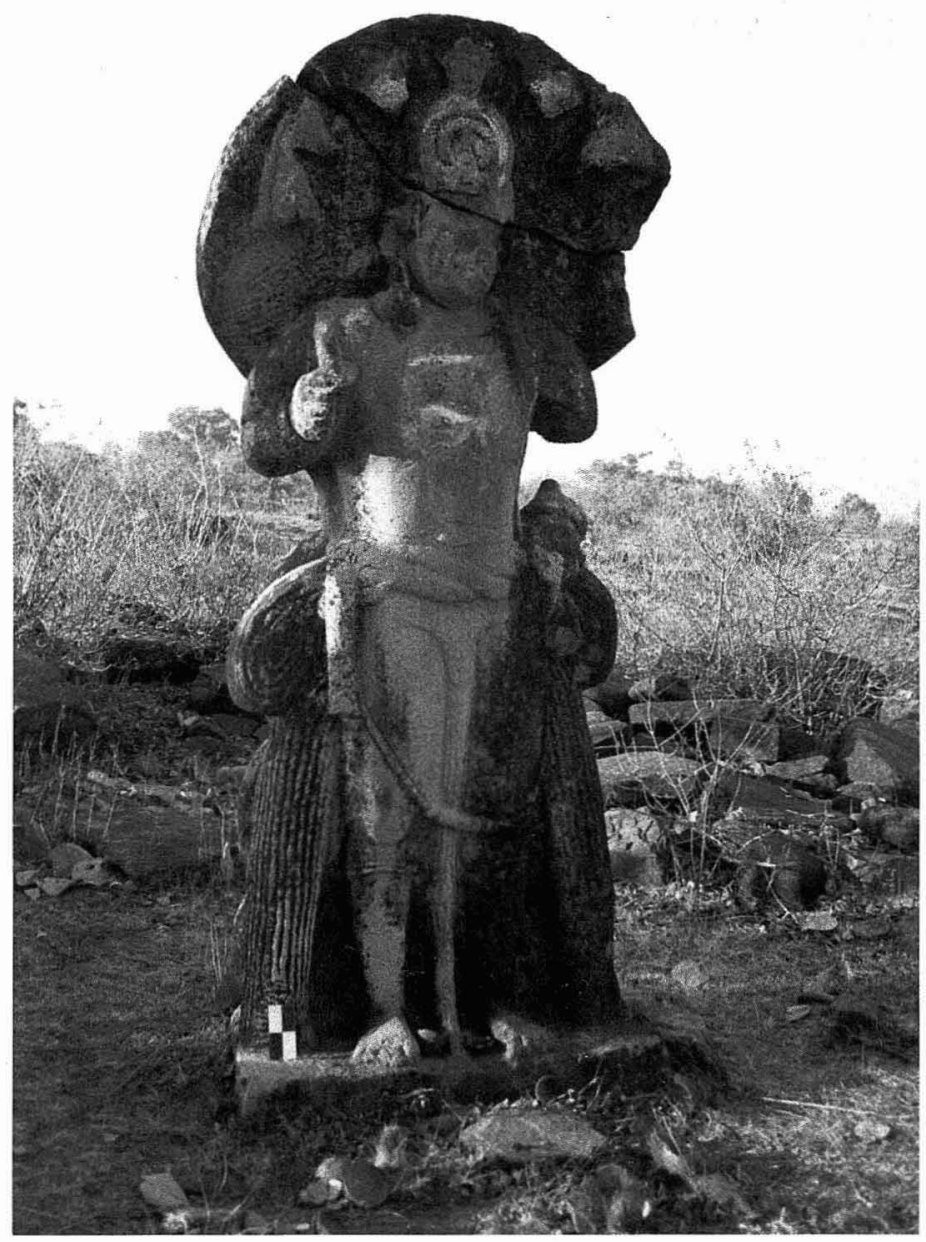

Fig. 7. Näga sculpture on Sanchi hill.

ern part of the study area, such as Ferozpur and Dhakna. Early papers (Shaw 2004; Shaw and Sutcliffe 2001) have posited a terminus ante quem of c. first century A.D. on the basis of the nāga sculpture (Fig. 7) whose current position at the foot of Nagauri hill corresponds with the edge of the ancient water body.

Regarding the actual construction of the dam, however, our working hypothesis accords closely with that of Marshall (1918:13), who suggested a date of third or second century B.C., in keeping with the main building phases at Sanchi and nearby sites. As discussed elsewhere (Shaw forthcoming; Shaw and Sutcliffe 2005), most of the hills to the west of Sanchi are occupied by Buddhist remains, while the lower slopes and agricultural plains are dotted with settlements yielding early historic ceramics. This particular configuration of dams, settlements, and ritual sites is a common feature of what elsewhere (Shaw and Sutcliffe 2001) has 


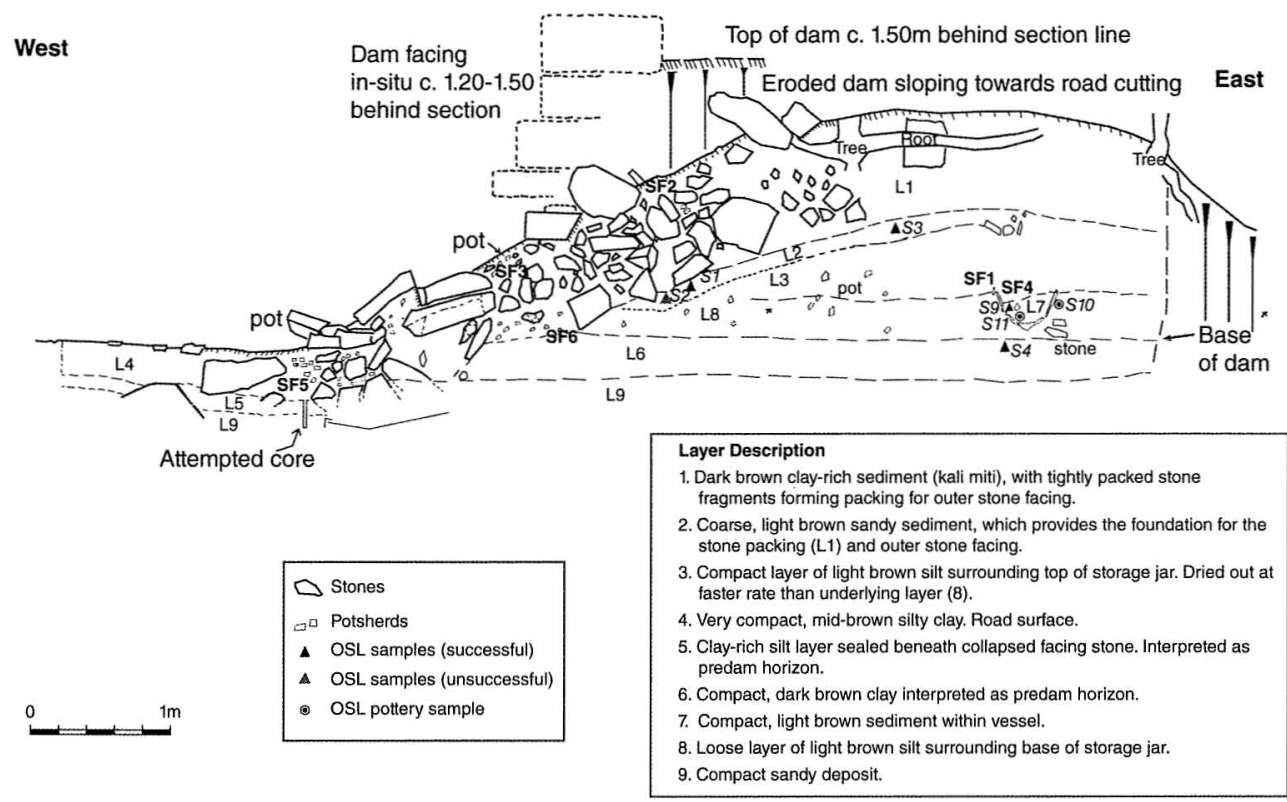

Fig. 8. Sanchi dam section (scaled drawing).

been termed the "early historic complex," which repeats itself throughout the Sanchi area and is central to our hypothesis regarding the development of exchange networks between monastic and nonmonastic populations.

Description of Dam Section in Modern Road Cutting - A modern road cutting at the southern limit of the main north-south dam was cleaned back to form a vertical section down to the present road surface. This revealed an earthen core with stone facing and packing on the upstream side (Figs. 8, 9, and 10). Many of the facing slabs have collapsed, probably during the cutting of the road. ${ }^{20}$ In order to reveal an intact profile of the facing, the section would need to be cut back c. $1.50 \mathrm{~m}$ to the north, where seven courses of vertically laid facing are still in situ; this was beyond the remit of our current research agreement. Nevertheless, a number of important construction details were revealed: the outer facing consists of two rows of large, horizontally laid stone slabs, varying in thickness from 0.10 to $0.40 \mathrm{~m}$. Although several of the larger stone blocks (average dimensions: $0.30 \times 0.20 \times 0.25 \mathrm{~m}$ ) were laid directly upon the earthen core, most were underlain by: an inner layer (L1) of tightly packed stone fragments (average dimensions: $0.15 \times 0.10 \times 0.10 \mathrm{~m}$ ), to a depth of $0.6 \mathrm{~m}$. As discussed elsewhere (Shaw and Sutcliffe 2003a: 76), this inner lining was evidently intended to provide filtration and drainage behind the masonry.

Over 500 potsherds were recovered from the dam core as well as the inner lining (L1) (Figs. 11 and 12). ${ }^{21}$ Insights into their original provenance and function within the dam are provided by house-building practices in local villages, where ancient potsherds are often visible in the walls of modern houses (S. B. Ota, pers. comm.). This is because the mortar used to bind stone courses is often based on sediment collected from ancient settlement mounds, which of course contain 


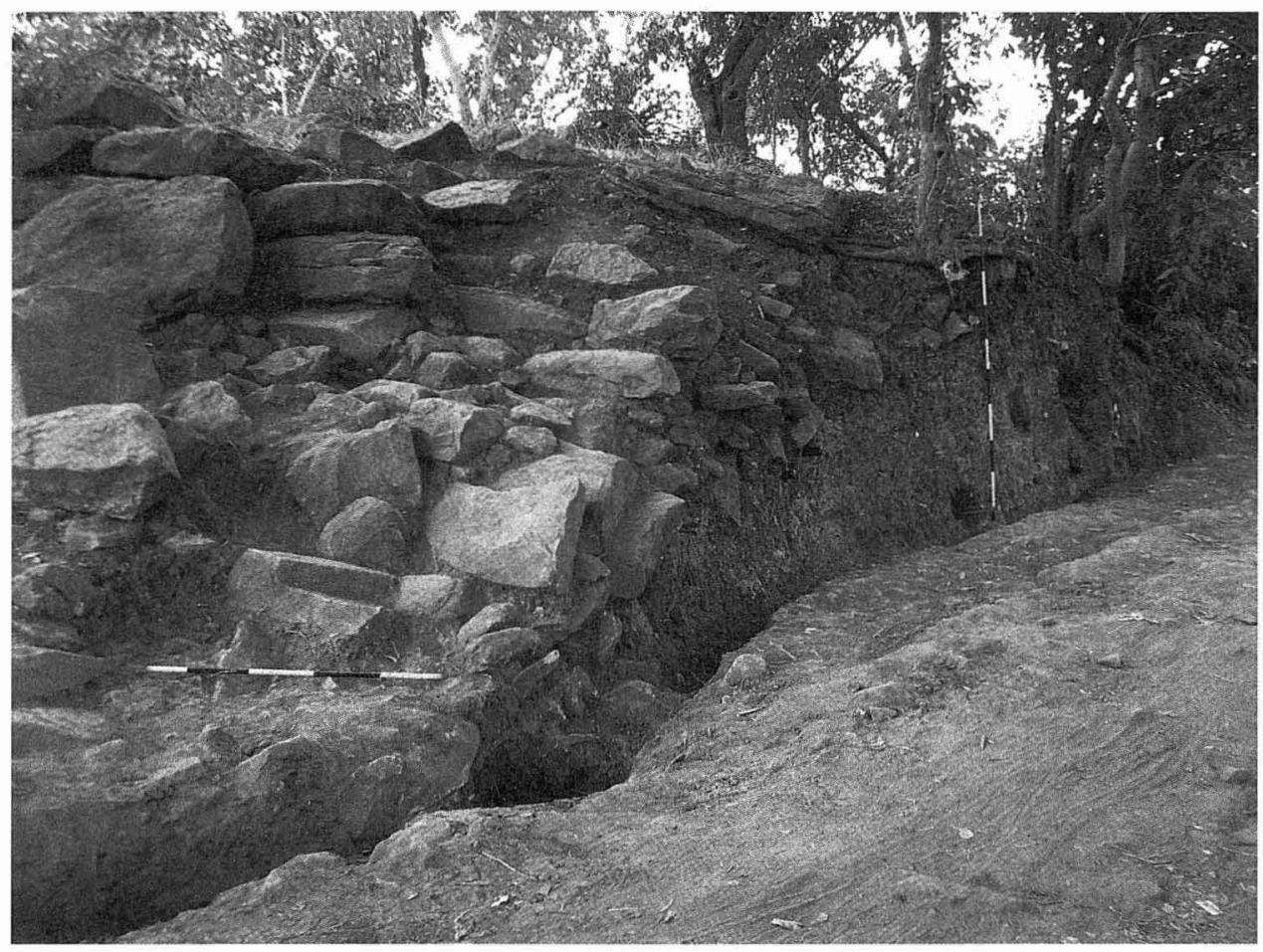

Fig. 9. Sanchi dam section taken from west showing location of samples and stone facing (note dressed masonry fragment in lower left corner).

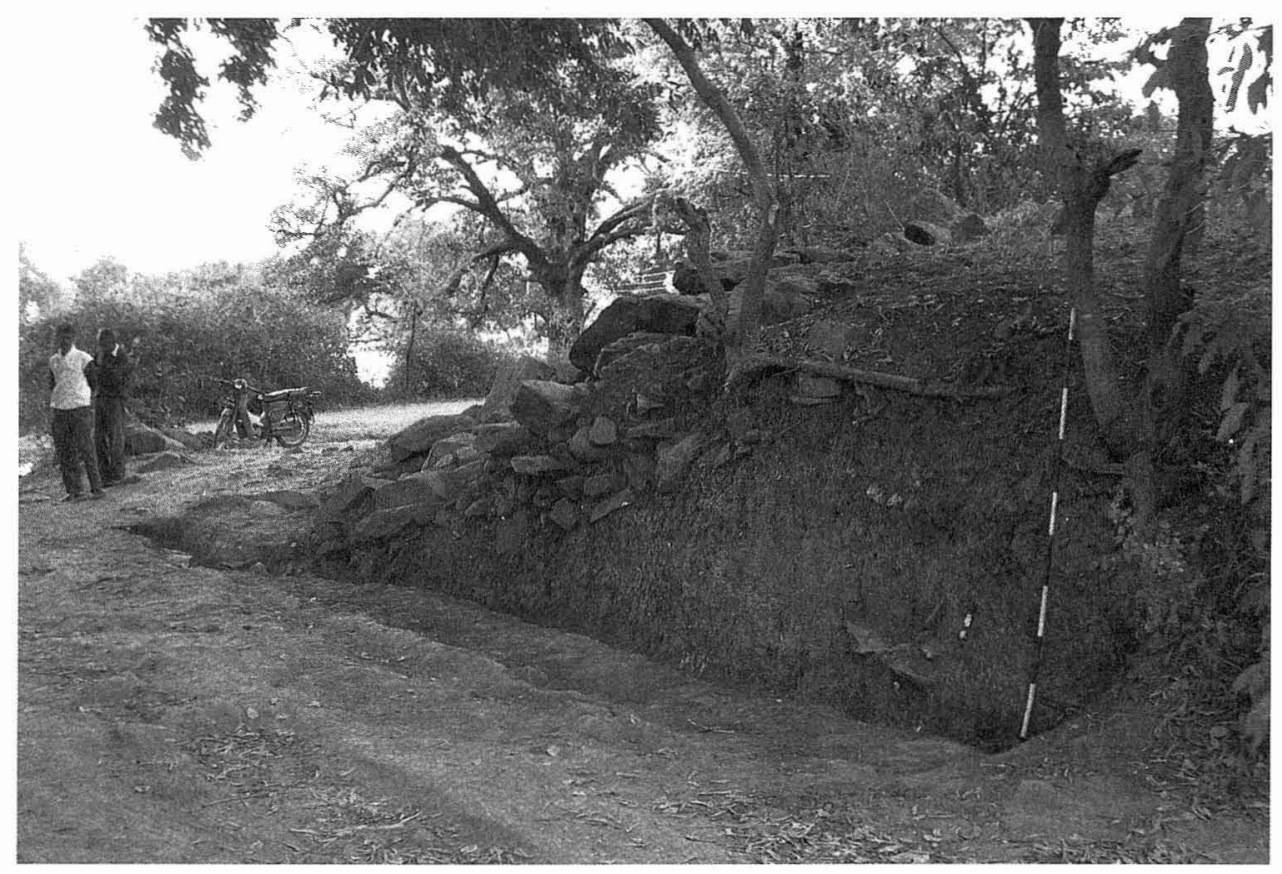

Fig. 10. Sanchi dam section from east, showing storage pot at base of dam. 
2.1

4.2

4.4

5.1

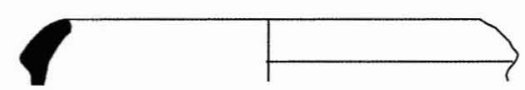

5.2

5.3

5.4

5.5
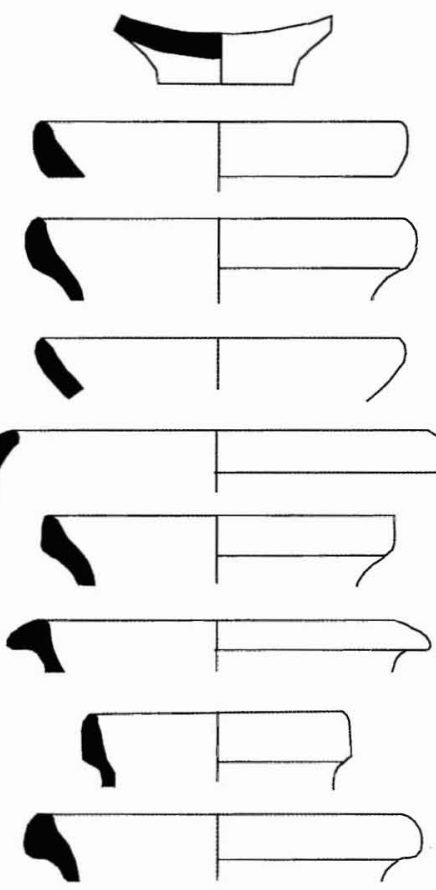

5.6

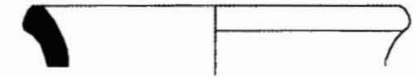

6.1

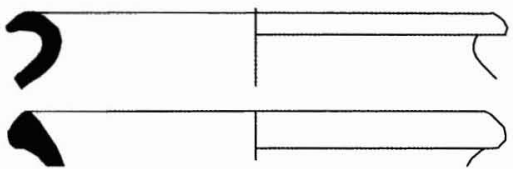

6.3

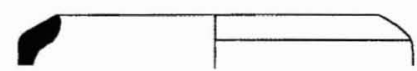

6.4
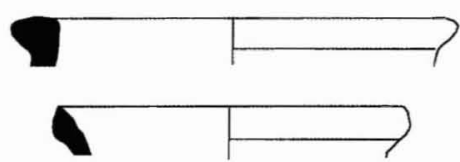

6.6

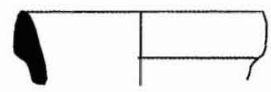

6.7
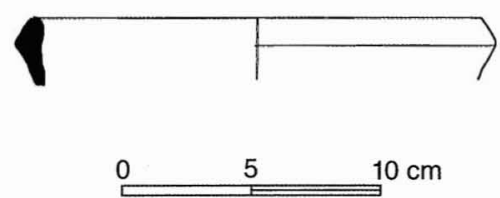

Fig. 11. Red ware potsherds (scaled drawings).

high quantities of ceramic fragments. These sediments are apparently favored because of their special "sticky" consistency. By analogy, therefore, the large quantities of potsherds in the Sanchi dam may have a similar explanation, collected for use in a mortar that has not survived, from a nearby settlement mound or spoil heap.

The sherds are mostly thinly slipped red wares, with several black wares. The absence of distinctive slips or decoration, together with the paucity of detailed ceramic descriptions and illustrations in relevant excavation reports, precludes comparisons with specific excavated material. However, broadly similar wares are recorded in stratified levels datable to c. third to first centuries B.C. at Vidisha and nearby sites such as Nandour, Ninnore, and Dangawada (see Fig. 1; Sharma and Misra 2003). ${ }^{22}$ One may assume, therefore, that the sherds in the Sanchi dam were collected from a nearby settlement mound datable to the late centuries B.C. Whilst providing a rough terminus post quem for the construction of the dam, the possibility that at least some of the sediment used in the main body of the dam came from Chalcolithic levels (either from the same or another settlement) is corroborated by luminescence dates from a storage jar found at the base of the dam and discussed below.

The dam core is made up of a variety of sediment layers (see Figs. 8 and 10). The upper layer (L1) surrounding the stone packing and continuing across the upper $0.60 \mathrm{~m}$ of the dam's crest is a dark brown clay-rich sediment, known locally as "black cotton soil" (käli miti). Immediately beneath the stone packing is a layer $0.10-0.12 \mathrm{~m}$ thick (L2) of coarse, light brown sandy sediment, which provides the foundation for the stone packing and outer stone facing. 


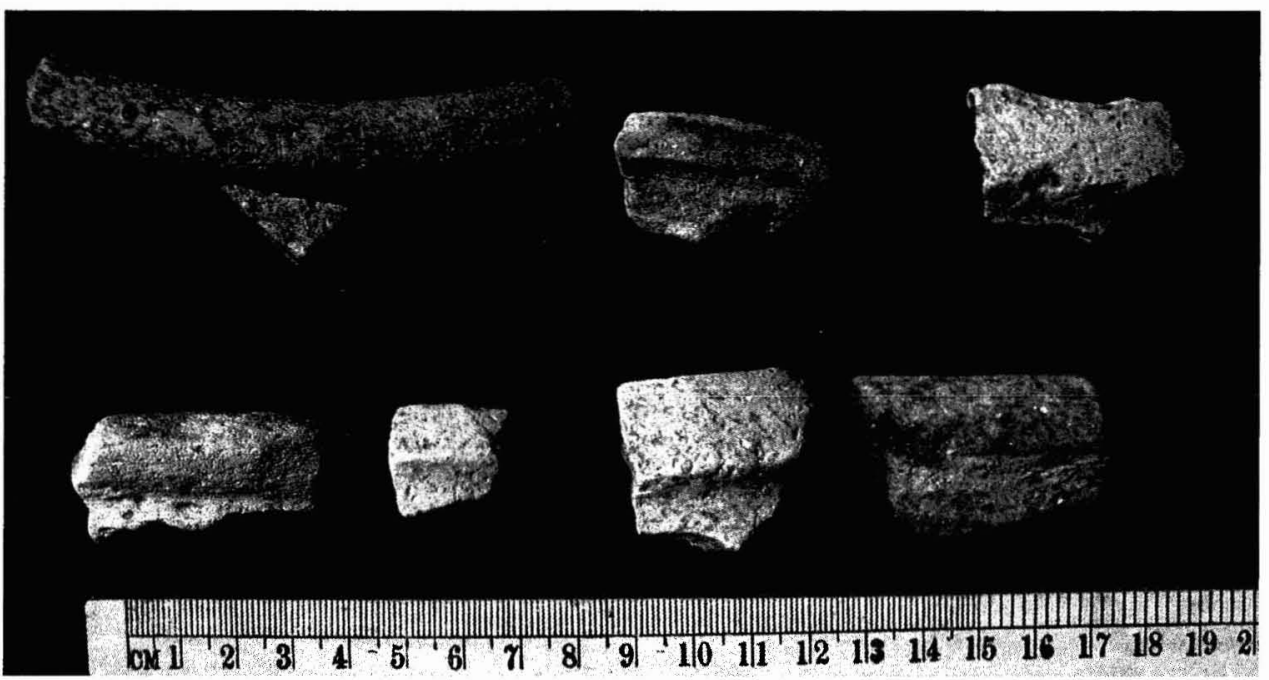

Fig. 12. Red ware potsherds from stone packing layer.

Beneath L2 are two more layers of black cotton soil (L3 and L8), distinguishable by their differential rates of dehydration. The boundary between L3 and L8 corresponds to the upper edge of a large broken ceramic vessel (SF1), positioned approximately midway across the dam section (see Figs. 8 and 10 ). It is $0.50 \mathrm{~m}$ at its widest point, with multiple fragments of in situ sherds of a black and red fabric $1.5 \mathrm{~cm}$ thick (Fig. 13). Its pronounced conical base is comparable to storage jars found at a number of Chalcolithic sites in Central and North India (Rakesh Tewari, pers. comm.). Only the lower half of the vessel, bisected along its vertical axis, remains in cross section in the dam. It was probably sliced through vertically during the cutting of the road. Since L3 cuts across its upper portion and because no rims have been found, it may be assumed that it was already in its current form - that is, without its upper half - at the time of deposition in the dam.

The jar is surrounded by a loose layer of light brown silt (L8) and underlain by a horizontal layer (L6) of compact, dark brown clay $0.10 \mathrm{~m}$ thick, which continues westward beneath the lowest level of stone packing on the upstream side of the dam. L6 is interpreted as the buried predam horizon, the inference being that the storage jar marks the base of the dam. ${ }^{23}$

Further support for this suggestion is provided by L5, a gray, clay-rich silt layer $0.10 \mathrm{~m}$ thick sealed beneath one of the collapsed facing stones on the west (upstream) side of the section. ${ }^{24}$ This is underlain by a compact sandy deposit, which is a continuation of L9 immediately below L6. Two factors point to L5 representing the buried reservoir deposit: (1) its position immediately below the upstream facing and (2) its similarity to lake sediments, described later, collected from cores upstream of the dam. The height differential between L5 and L6 may be the result of soil removal on the upstream side for use in the construction of the dam.

OSL Dates from the Dam - Four OSL sediment dates were run on samples collected from separate contexts within and below the dam. Luminescence dates were also 


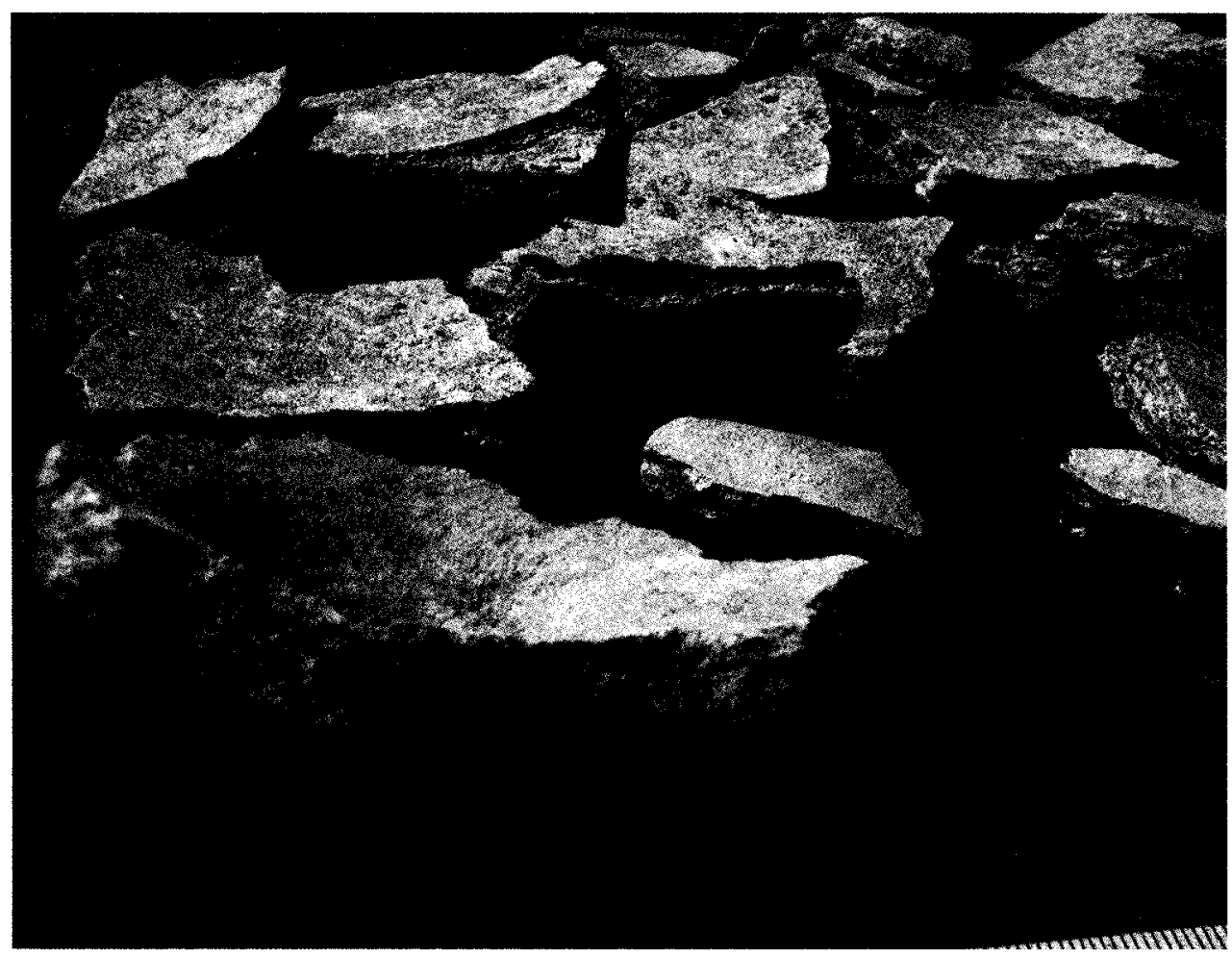

Fig. 13. Black and red ware fragments of storage jar (with portion of pointed base in lower left corner).

derived from two fragments of the storage jar at the base of the dam, as well as a sherd belonging to a separate vessel found amongst the sediment (L7) inside the jar (Table 1).

The first sample (S1) was collected from the sandy layer (L2) immediately beneath the lowest level of stone packing, the assumption being that the OSL clock was reset to zero before the sediment was sealed by the stone slabs above. This yielded a date of c. 450 B.C. ( \pm 240 years), which accords closely with our working hypothesis that it was built in the third or second century B.C., in keeping with the main building phases at Sanchi and nearby Buddhist sites. The second sample (S3), from the same layer further toward the center of the dam, gave an unexpectedly early date of c. 1780 B.C. ( \pm 460 years). This may be due to contamination caused by the roots of the large tree on the dam's summit (see Fig. 9). An alternative explanation is that the OSL in the sediment failed to be reset to zero prior to its deposition in the dam and therefore retained the time signature of the presumably Chalcolithic spoil heap from which it was excavated. The third sample (S4), from the buried predam layer (L4) beneath the storage jar, provided an even earlier date of c. 3680 B.C. ( \pm 630 years), probably representing Holocene alluvial deposits washed in from river action over the years prior to the construction of the dam. The fourth OSL sample (S9), taken from the sediment (L7) found in- 
Table i. Luminescence Dating Results from Dam Sections and Reservoir Cores

\begin{tabular}{|c|c|c|c|c|c|c|c|c|}
\hline SITE & SAMPLE NO. & CONTEXT & LAYER/DEPTH & NOTES & MATERIAL & OSL & PRELIMINARY AGE ESTIMATES & RELIABILITY \\
\hline Sanchi & S1 & Section & L2 & Below stone facing & Sediment & OSL (tube) & с. 450 в.с. ( \pm 240 years $)$ & High \\
\hline Sanchi & S3 & Section & L2 & Below stone facing & Sediment & OSL (tube) & с. 1780 в.С. ( \pm 460 years $)$ & Low \\
\hline Sanchi & S4 & Section & L6 & Predam horizon & Sediment & OSL (tube) & c. 3680 в.с. ( \pm 630 years $)$ & High \\
\hline Sanchi & S8 & Section & L7 & Contents of storage jar & Potsherd & OSL (ceramic) & с. 1360 в.с. ( \pm 270 years $)$ & High \\
\hline Sanchi & S9 & Section & L7 & Contents of storage jar & Sediment & OSL (bag) & c. 210 A.D. ( \pm 190 years $)$ & High \\
\hline Sanchi & $\mathrm{S} 10 \mathrm{a}$ & Section & L8 & Storage jar fragment & Potsherd & OSL (ceramic) & с. 2930 в.C. ( \pm 770 years $)$ & High \\
\hline Sanchi & $10 \mathrm{~b}$ & Section & L8 & Storage jar fragment & Potsherd & OSL (ceramic) & с. 1750 в.с. ( \pm 750 years $)$ & High \\
\hline Sanchi & S19 & Core 4 & $0.73-0.82 \mathrm{~m}$ & Reservoir deposit & Sediment & OSL (bag) & c. 590 A.D. ( \pm 220 years) & Low \\
\hline Sanchi & $\mathrm{S} 21$ & Core 4 & $0.90-1.00 \mathrm{~m}$ & Predam horizon & Sediment & OSL (bag) & c. 790 A.D. ( \pm 120 years $)$ & Low \\
\hline Karondih & $\mathrm{K} 3$ & Core 1 & $1.29-1.38 \mathrm{~m}$ & Reservoir deposit & Sediment & OSL (bag) & с. 7210 в.C. ( \pm 740 years $)$ & Low \\
\hline Karondih & $\mathrm{K} 4$ & Core 1 & $1.38-1.47 \mathrm{~m}$ & Predam horizon & Sediment & OSL (bag) & с. 13,610 в.с. ( \pm 1320 yrs $)$ & Low \\
\hline Devrajpur & D20 & Section & N/A & Below stone packing & Sediment & OSL (tube) & с. 4160 в.С. ( \pm 580 years) & Low \\
\hline Devrajpur & D21 & Section & N/A & $\begin{array}{l}1 \mathrm{~m} \text { below stone packing } \\
\text { in southern sounding }\end{array}$ & Sediment & OSL (tube) & с. 1280 в.C. ( \pm 460 years $)$ & Low \\
\hline Devrajpur & D26 & Section & N/A & Behind packing stone & Sediment & OSL (tube) & c. 2800 B.c. ( \pm 490 years $)$ & Low \\
\hline Devrajpur & D5 & Core 1 & $2.25-2.36 \mathrm{~m}$ & Reservoir deposit & Sediment & OSL (bag) & с. 1760 в.с. ( \pm 640 years $)$ & Low \\
\hline Devrajpur & D8 & Core 1 & $2.96-3.04 \mathrm{~m}$ & Predam horizon & Sediment & OSL (bag) & c. 2730 в.с. ( \pm 880 years $)$ & High \\
\hline
\end{tabular}


side the storage jar, will be discussed below, following a consideration of the date of the vessel itself.

Luminescence dates were obtained from two separate sherds from the storage jar (S10a and b), producing divergent dates of c. 2930 в.c. ( \pm 770 years) and c. 1750 в.C. ( \pm 750 years). This disparity of over 1000 years is possibly the result of irregularly released thermoluminescence throughout the vessel due to ill-firing. ${ }^{25}$ Additional distortions were possibly introduced by the clay's high feldspar content, a known factor in reducing the efficacy of silica-based analysis. ${ }^{26}$ In the meantime, it is interesting to note that $\mathrm{S} 10 \mathrm{~b}$ produced a similar date (c. 1750 B.C. \pm 750 years) to S3, which as discussed above probably came from a Chalcolithic spoil heap.

An OSL date of c. 1360 B.C. ( \pm 270 years) was obtained from a sherd (S8) of a separate vessel found amongst the sediment (L7) inside the storage jar. This accords closely with the OSL dates (S10b) from the storage jar itself and from L2 (S3) and provides further evidence that at least some of the building material came from a Chalcolithic context. Interestingly, however, the final OSL sample (S9), taken from L7 (the sediment inside the storage jar) in which S8 was found, yielded a much later date of c. 210 A.D. ( \pm 190 years). Such widely divergent dates might reasonably be explained as follows: the storage jar was dug out, along with its contents, from Chalcolithic levels at a nearby mound, sometime in the late centuries B.C. While the single potsherd (S11) inside retained its original time signature - that is, roughly contemporary to the storage jar-the actual sediment was exposed to light during the transportation of the jar and thus had its OSL clock reset to zero. Taking into account the error margin of $S 9$ ( \pm 190 years), together with the date range for S1 from L2 (450 B.C. \pm 240 years), the most reliable OSL sample from the main body of the dam, one may propose a third to second century B.C. date for the dam's actual construction. This accords closely with the suggested chronology, discussed earlier, of the potsherds found in the stone packing.

Reservoir Sediments - Four cores were drilled at two separate locations (see Fig. 5 and 6) with the aim of establishing reservoir depth and collecting samples for OSL dating and pollen analysis: (1) three cores within the main reservoir bed, approximately $180 \mathrm{~m}$ north of the east-west retaining dam and (2) another approximately $100 \mathrm{~m}$ upstream of the Karondih dam to the west. All four cores followed a similar sequence, reaching a total depth of 1.40-1.45 $\mathrm{m}$ in the main Sanchi reservoir and $1.70 \mathrm{~m}$ in the smaller Karondih reservoir. The upper $0.85 \mathrm{~m}(1.30 \mathrm{~m}$ at Karondih) consisted of a gray, clay-rich sediment with fine laminations of black organic material, sandstone grit, and subangular $(<2 \mathrm{~mm})$ calcitic inclusions. Between 0.85 and $1.00 \mathrm{~m}$ there was a change to a fine, mid-gray, stone-free clay, interpreted as the basal reservoir sediment. Beneath this $(1.00-1.20 \mathrm{~m})$, the sediment was increasingly stony, followed by a change to a light brown to orange "clean" silt, which was interpreted as the prereservoir buried sediment. At $1.20 \mathrm{~m}$, there was a change to the stony subsoil, known locally as pili miti (literally "yellow soil"). The sequence at Karondih was similar, with the yellow subsoil occurring at $1.60 \mathrm{~m}$.

OSL Dates from the Reservoir Deposits - Four OSL samples, two from each of the coring locations, were collected from the Sanchi reservoir complex. All yielded unreliable dates for different reasons. At the main reservoir site, S19 from the lake 
sediment and S21 from the buried subsoil produced dates of c. 590 A.D. $( \pm 220$ years) and c. 790 A.D. ( \pm 120 years) respectively. Given the OSL dates from the dam section, these are unfeasibly young and may be regarded as erroneous, probably due to light contamination incurred during sampling or some other disturbance in historic times. By contrast, at Karondih, samples from similar contexts (K3 and K4) produced excessively early dates of c. 7210 в.с. ( \pm 740 years) and c. 13,610 B.C. ( \pm 1320 years) respectively. These probably reflect the depositional age of pre-existing Holocene alluvial deposits.

\section{The Devrajpur Reservoir Complex}

Archaeological Context - The Devrajpur dam is situated about $14 \mathrm{~km}$ to the southeast of Sanchi (see Fig. 1). It is the largest dam in the study area, with an average height of $4.5 \mathrm{~m}$, a length of $1 \mathrm{~km}$, and an estimated area and volume capacity of $1.86 \mathrm{~km}^{2}$ and $3.8 \mathrm{~m}^{3} \times 10^{6}$ respectively (Shaw and Sutcliffe 2005:15). It is also the best preserved, ${ }^{27}$ with a number of advanced design features including a spillway at the eastern abutment of the dam (Fig. 14) and remains of a monumentalized control structure over the main feeder stream to the west (Shaw and Sutcliffe 2003a, 2005). Unlike Sanchi, it appears that the dam was probably designed for downstream irrigation, as were other dams in the eastern zone (Shaw and Sut-

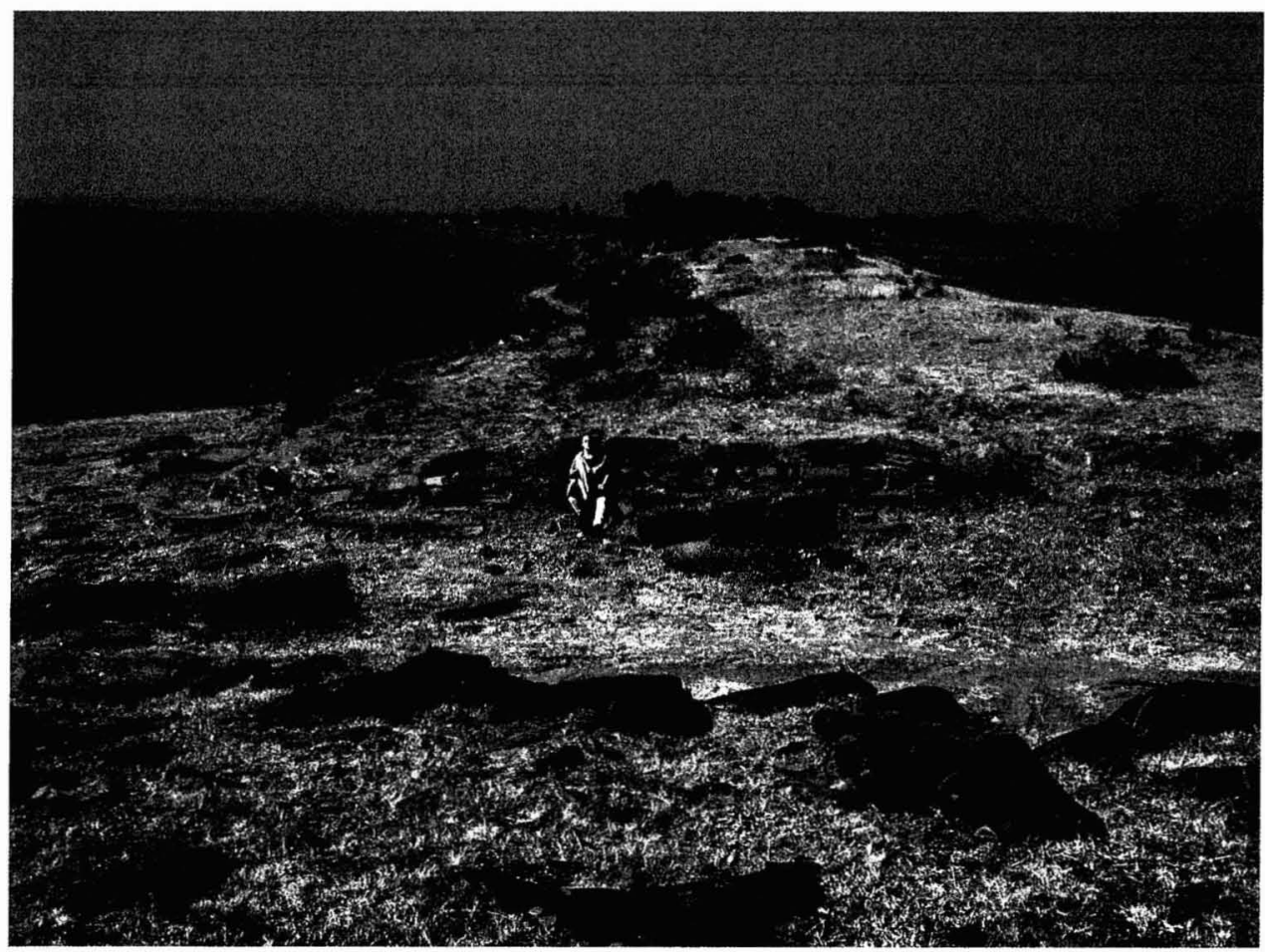

Fig. 14. Devrajpur dam from eastern escarpment, with spillway in foreground. The line of trees marks the location of the road cutting. 


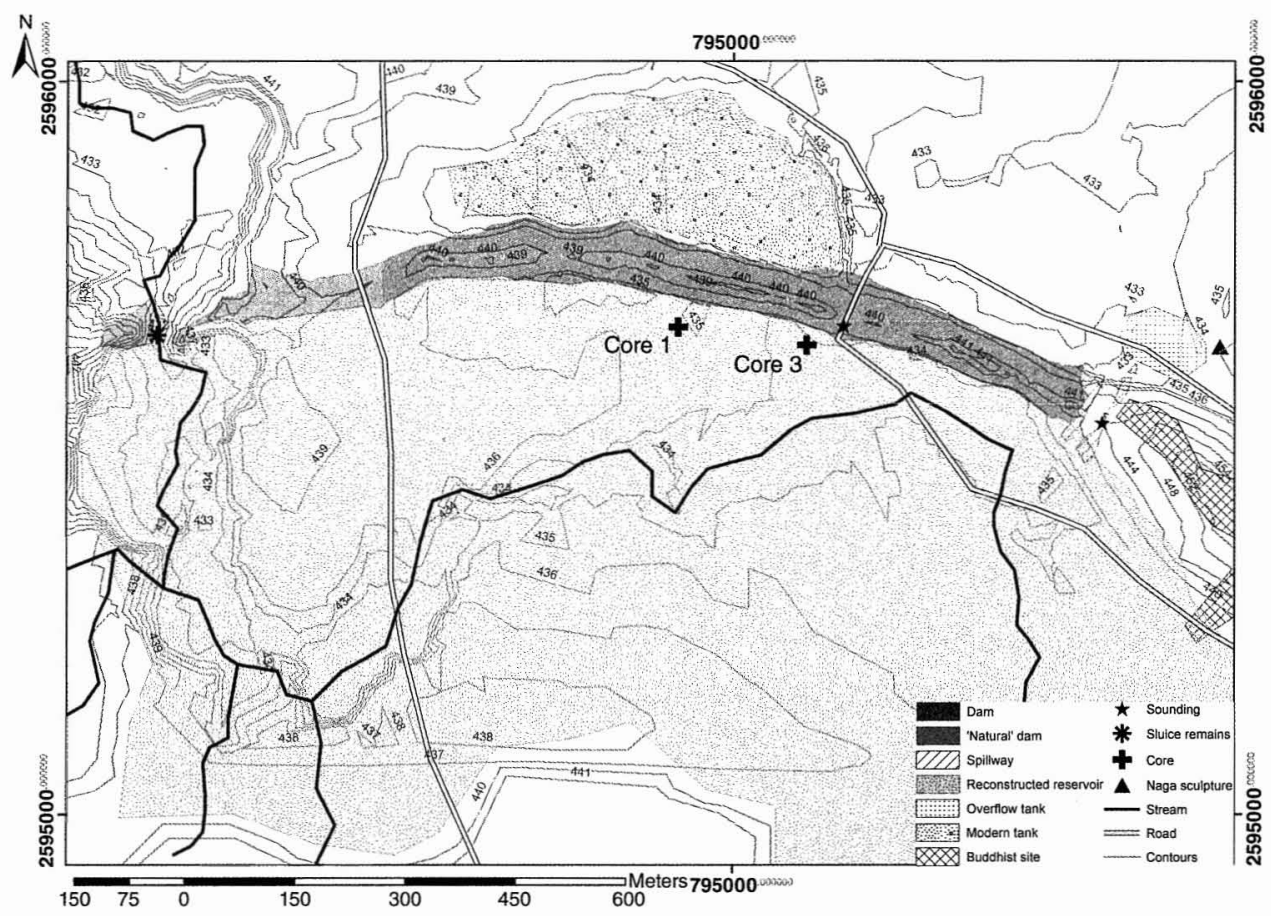

Fig. 15. Map of the Devrajpur dam complex (contours generated from Total Station and satellite imagery).

cliffe 2005). Early papers posited a terminus ante quem date of c. fifth century A.D. (Shaw and Sutcliffe 2001: Fig. 26, 2003a) on the basis of a serpent stone (nägakal) to the northeast of the dam (Fig. 15). In keeping with the dynamics of the "early historic complex" throughout the Sanchi area, the hill at the eastern end of the dam is occupied by an extensive Buddhist complex including heavily damaged stüpas and monasteries, which like other Buddhist sites on the surrounding hills may date to c. second to first century B.C. (Shaw and Sutcliffe 2005:1617, Fig. 27). Further, various early historic settlements are scattered throughout the neighboring plains and lower hill slopes. Together with the similarity of the dam's stone facing with that at Sanchi, the dam's spatial relationship to the wider archaeological landscape suggests a constructional date in the late centuries B.C. The present study aimed at testing this hypothesis through the collection and study of sediment samples from within and beneath the dam and the reservoir bed.

Description of Dam Section in Modern Road Cutting - An exposed section formed by a modern road cutting, approximately midway along the main dam, was chosen for further investigation (see Figs. 14 and 15). With a width of $70 \mathrm{~m}$, the dam is much wider than Sanchi. The road cutting does not extend to the base of the dam but follows its general contours, with an average height differential of less than $2 \mathrm{~m}$. Thus a small vertical section, $8 \mathrm{~m}$ long and $1.30 \mathrm{~m}$ high, was cut back to the level of the road (Figs. 16, 17, and 18). In order to obtain a complete dam 


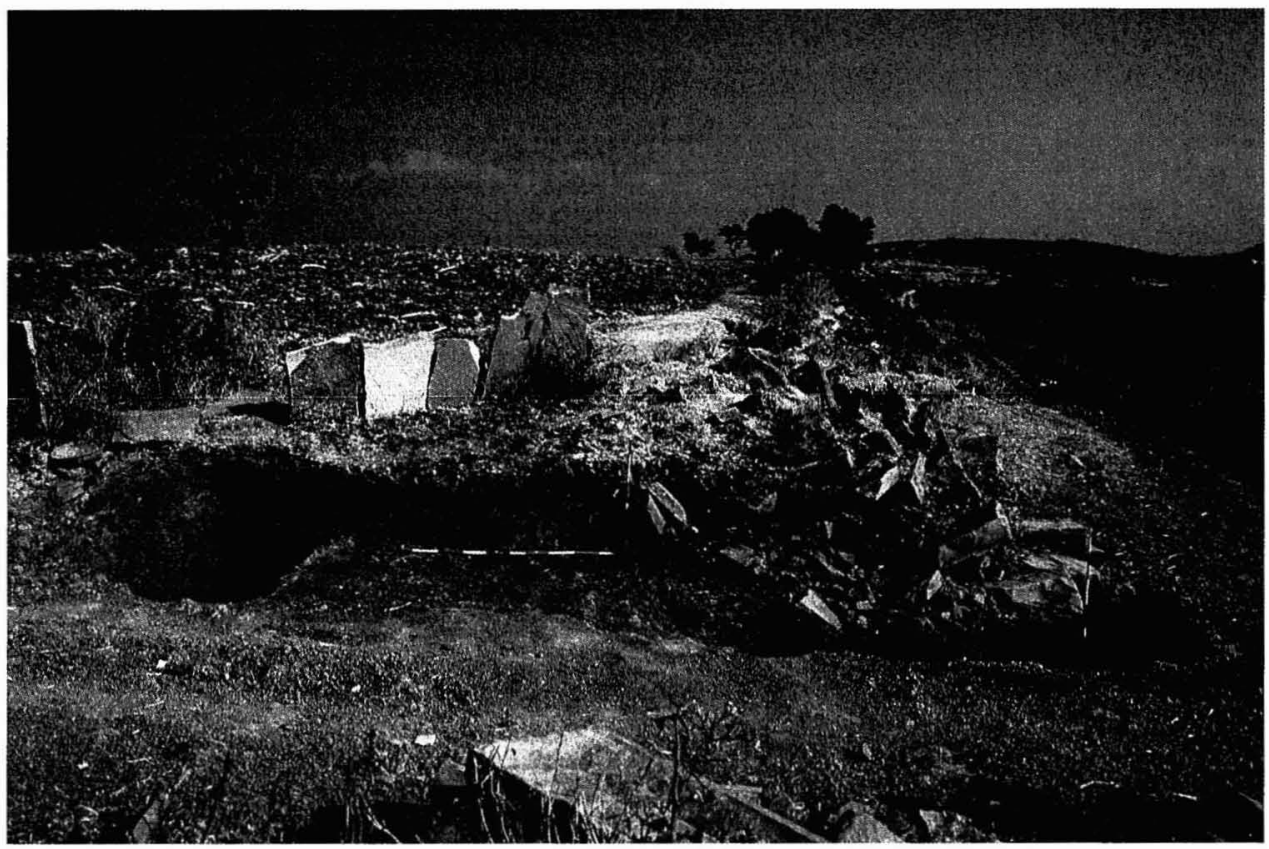

Fig. 16. Devrajpur dam section.

profile, two small soundings were excavated in front of the section at its northern and southern edges, measuring $1.80 \times 1.50 \mathrm{~m}$ and $3.35 \times 1.10 \mathrm{~m}$, respectively. Reaching a depth of $1 \mathrm{~m}$ below the base of the stone facing, the soundings provided information about the construction of the dam and its relationship to the predam horizon.

As at Sanchi, the dam consists of an earthen core, faced on the upstream side with large stone blocks interspersed by smaller packing stones. However, unlike the Sanchi dam, which contains different sediment layers, the Devrajpur core consists entirely of homogeneous black cotton soil with no discernible stratigraphy. While the Sanchi dam section contained high levels of sand due to its proximity to the adjoining hill, the Devrajpur road cutting was situated midway along the dam, where it is difficult to distinguish between the black cotton soil in the embankment and the black cotton soil beneath the lowest course of stone facing; the same homogeneous deposit continued to the base of the two soundings at either end of the section.

A core $2 \mathrm{~m}$ deep (no. 4) was drilled into the base of the southern sounding, reaching a total depth of $3 \mathrm{~m}$ below the stone facing base (see Figs. 17 and 18). Homogeneous black cotton soil deposits continued throughout, interspersed only at about $1.7 \mathrm{~m}$ by several tiny eroded brick fragments that had probably worked their way down through cracks in the black cotton soil, formed during the dry season, and known to reach up to $5 \mathrm{~m}$ in depth (Hodnett and Bell 1986:364). We may assume, therefore, that the dam did not continue below the lowest course of stone facing visible in the road cutting section. This conforms to the dam profile at Sanchi and also to modern examples of dam design: since the prin- 


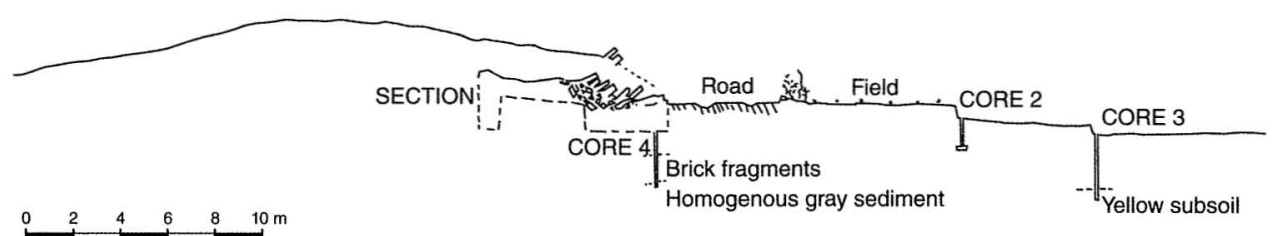

Fig. 17. Devrajpur dam profile (scaled drawing), showing location of section and cores.

cipal function of stone facing is to provide protection from water damage, it would make little sense if the facing did not continue to the base of the dam (Shaw and Sutcliffe 2001).

Stone Facing and Inner Packing - The total breadth of surviving stone facing from the outer edge of the dam is $3 \mathrm{~m}$, with a height of $1.30 \mathrm{~m}$ (see Figs. 16 and 18). The two lower horizontal courses consist of large, roughly hewn slabs (average dimensions: $1.20 \times 0.80 \times 0.30 \mathrm{~m}$ ), with seven further courses of well-dressed slabs above (average dimensions: $0.12-0.30 \times 0.70 \times 0.60 \mathrm{~m}$ ). As at Sanchi, some of these protrude from the body of the dam at a pronounced upward facing angle, especially where water velocity and risk of damage was at its highest (Shaw and Sutcliffe $2001: 61$ ).

Behind the larger facing stones is an area of smaller, tightly packed, angular stone fragments (average dimensions: $0.20 \times 0.20 \times 0.10 \mathrm{~m}$ ) continuing into the body of the dam for a further $0.80-1.00 \mathrm{~m}$. Unlike Sanchi, no evidence for mortar was found in the packing, although it is reported that until recently, a type of mortar known as siśs $\bar{a}$ (literally, "glass") was collected from the cracks between the facing stones for reuse in modern buildings. ${ }^{28}$

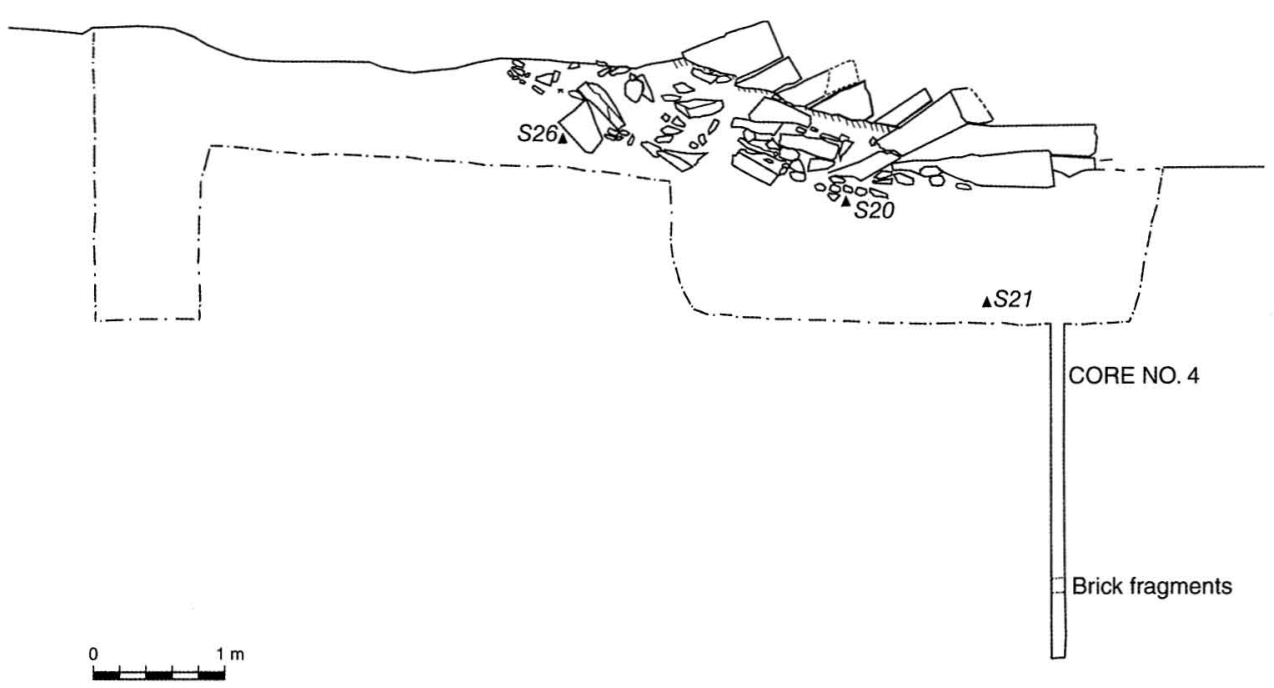

Fig. 18. Devrajpur dam: Detail of section (scaled drawing). 
OSL Dating of the Dam - Samples for OSL dating were collected from three locations within the road cutting section (see Fig. 18 and Table 1): (1) directly under the base of the stone packing (D20); (2) $1 \mathrm{~m}$ below the stone packing, at the base of the southern sounding (D21); and (3) directly behind a medium-sized inner packing stone laid on top of the earthen core (D26). However, all produced unfeasibly early dates: D20 = c. 4160 B.C. $( \pm 580$ years $) ; D 21=$ c. 1280 B.C. ( \pm 460 years); and D26 = c. 2800 B.C. $( \pm 490$ years). A likely explanation is that the OSL signal from these samples may not have been fully reset during the excavation of the sediment used to construct the dam. It might be relevant that the black cotton soil was probably dug out nearby and thus had less chance of being exposed to light. In the case of D20 and D26, the overlying facing stones may have skewed the results further. ${ }^{29}$ However, the general date range is in keeping with that expected of predam alluvial deposits from the Holocene, washed in from river action over the years prior to the construction of the dam.

Reservoir Sediments - Seven cores were drilled at three different locations upstream and downstream of the dam (see Fig. 15): (1) within the main reservoir bed upstream of the dam; (2) within the lower basin, to the west of the dam; and (3) within the bed of the small overflow tank downstream of the spillway at the dam's eastern extent. Only the two most successful cores, from the first location, are described here.

Core 1 was drilled to a depth of $3.10 \mathrm{~m}$ in a shallow depression midway along the dam. It is identifiable on Figure 14 as a relatively light green area of wheat and lentils (masur) in an otherwise dark green field of chickpeas (channa). ${ }^{30}$ Immediately downstream is a modern tank, reportedly built within the last century, which seems to be recharged from infiltration partially derived from this depression.

Down to $2.5 \mathrm{~m}$, the core comprised reservoir silts consisting of gray, clay-rich sediment with fine laminations of black organic material. Between 2.50 and 2.90 $\mathrm{m}$, this changed to brown, humus-rich sediment, followed by "clean" gray, clayrich sediment. The yellow stony subsoil (pili miti) appeared at $3.0 \mathrm{~m}$, following a transitional layer of brown-stained sediment that probably represents the predam buried sediment horizon.

A second core (no. 3) was drilled to a depth of $2.4 \mathrm{~m}$ approximately $30 \mathrm{~m}$ upstream of the road cutting section to provide a cross-check for Core 1 , which seemed surprisingly deep given its proximity to the dam. The upper $1.80 \mathrm{~m}$ consisted of homogeneous gray, clay-rich sediment, with occasional shell and stone grit inclusions. Below this was a brown stony sediment followed by the yellow subsoil. Given the interpreted base level of the dam discussed earlier, the upper $1.80 \mathrm{~m}$ probably represents predam alluvial or lacustrine sediments that were subjected to periodic waterlogging during the dam's lifetime. The same applies to the black cotton soil underlying the dam, as represented in Core no. 4 from the southern sounding. The obvious question here is: why does Core no. 1 contain such a deep reservoir sequence? One suggestion, which could be tested by studying a complete column core sequence, is that we are dealing with a natural oxbow-or possibly even an older palaeotank - that was incorporated into the early historic reservoir system. The high levels of shell inclusions in the core support this suggestion. 


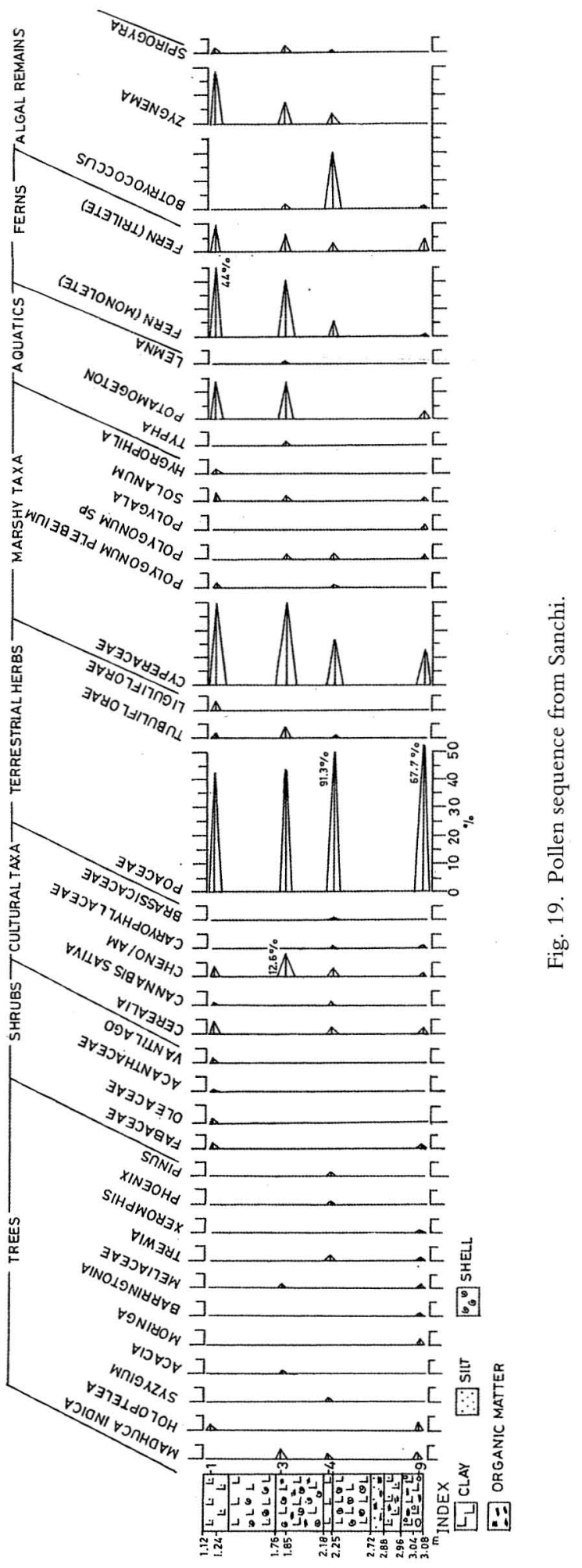




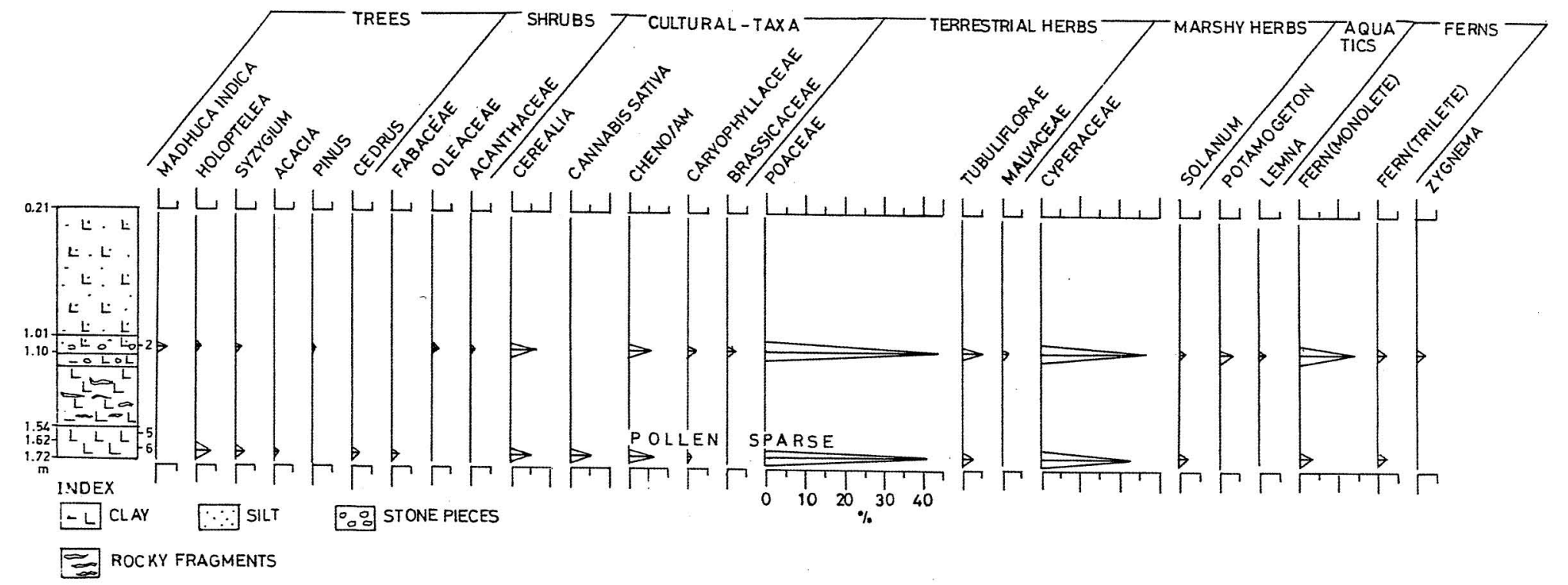

Fig. 20. Pollen sequence from Karondih. 


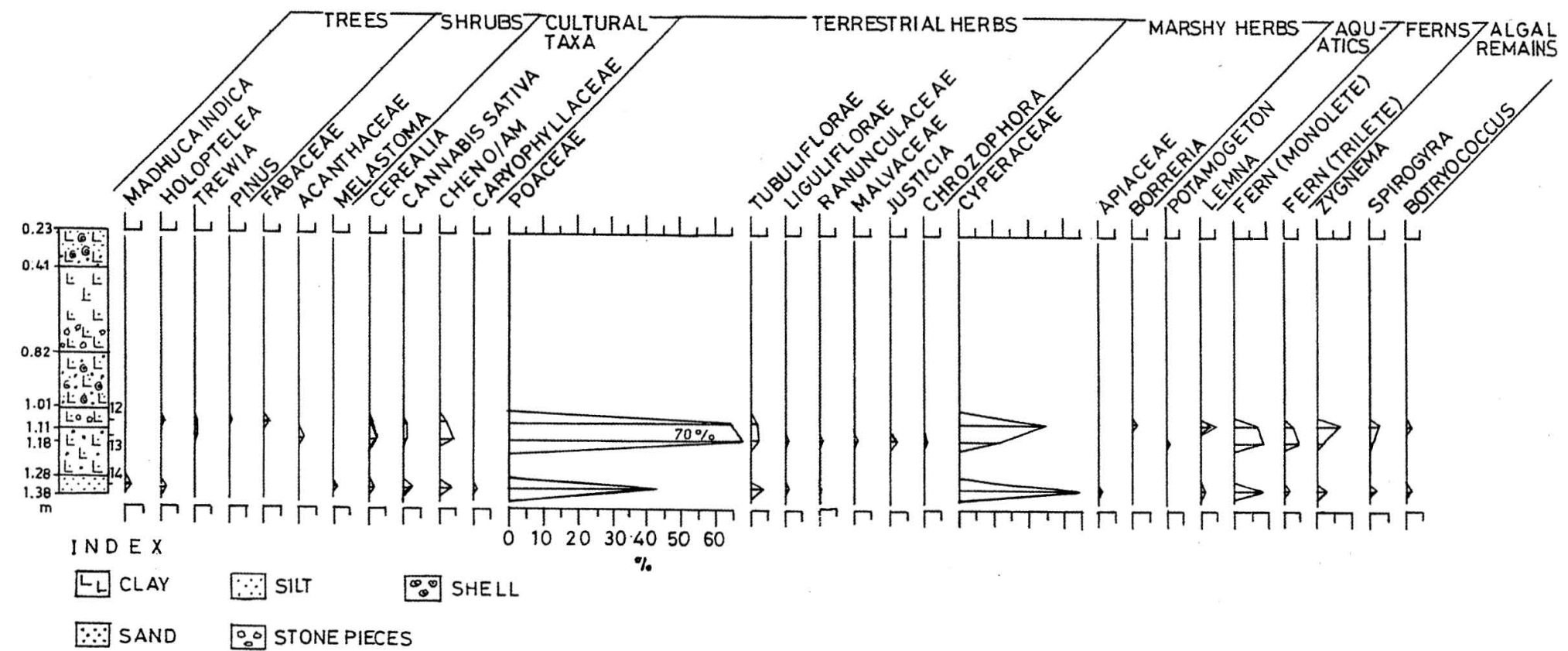

Fig. 21. Pollen sequence from Devrajpur. 
Dating the Reservoir Sediments - Two OSL samples were collected from Core 1: D5 from the reservoir silts, and D8 from the predam horizon, yielding dates of с. 1760 в.с. ( \pm 640 years) and c. 2730 в.C. ( \pm 880 years) respectively. As before, we are probably dealing with Holocene deposits not sufficiently exposed to light for the OSL to be reset to zero.

\section{POLLEN ANALYSIS}

Six sediment core samples from Sanchi, Devrajpur, and Karondih were studied for their phytolith content, with entirely negative results. As discussed earlier, a precise identification of the types of crops associated with the dams awaits further sampling from nearby settlement sites. By contrast, pollen-extracted from nine sediment core samples from all three sites using the standard technique of acetolysis (Erdtman 1943) - yielded positive results, with an average pollen sum of 105 to 175. Although these sequences cannot lead to the identification of specific agricultural crops, they are useful for providing a broad palaeovegetative and climatic setting for the Sanchi dams (Figs. 19-22; Table 2).

At all three coring locations, samples were selected for pollen analysis from three different levels within the sediment core: (1) the middle of the reservoir silts, (2) the base of the silts, and (3) the underlying buried sediment. The resulting sequences were roughly similar, with most variation reflecting differences in area and volume of the respective water bodies. All three reservoirs seem to have been surrounded by open grassland vegetation during the course of sediment accumulation. Grasses (Poaceae) were the dominant species, followed by Astera-

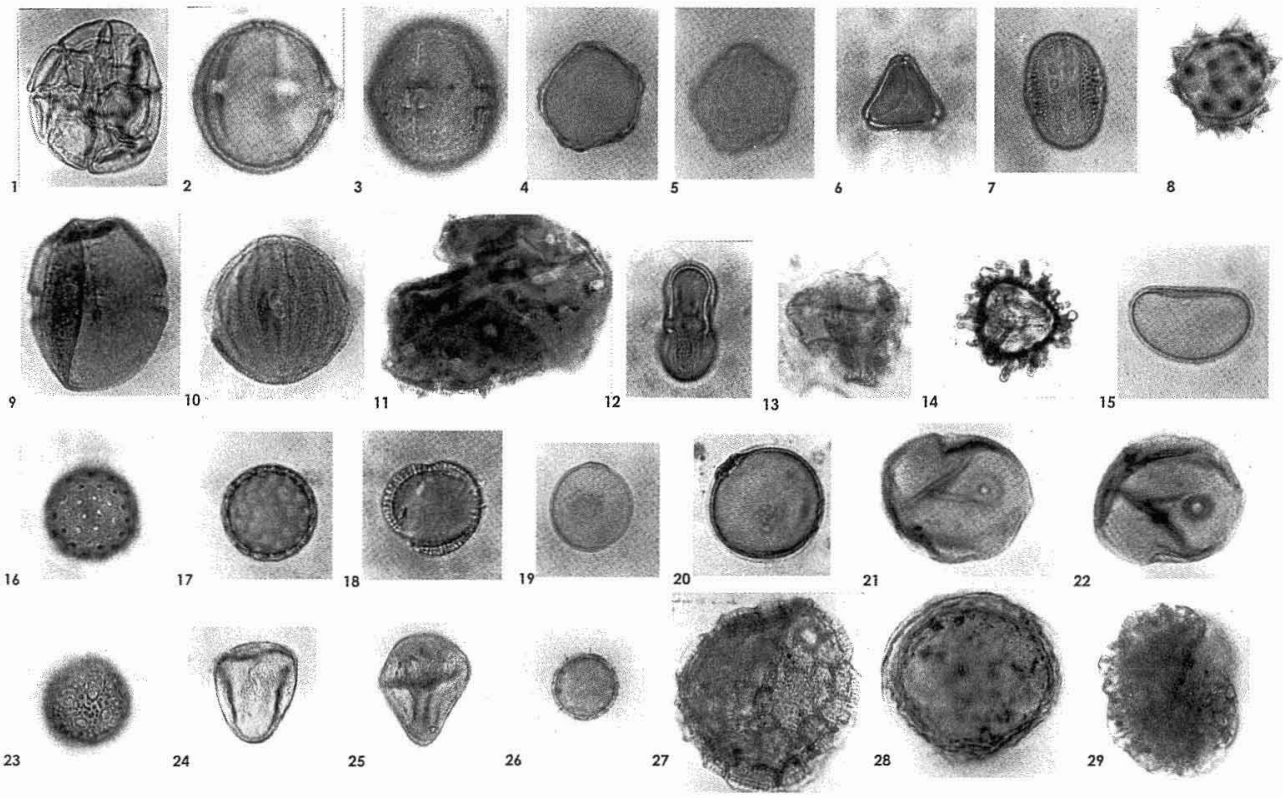

Fig. 22. Pollen and spores from sediment core samples (see Table 2 for details). 
Table 2. Details of Pollen and Spores Illustrated in Figure 22

\begin{tabular}{|c|c|c|c|c|c|c|c|}
\hline 1 & Acacia & 2 & Madhuca indica & 3 & Madhuca indica & 4 & Holoptelea \\
\hline 5 & Holoptelea & 6 & Syzygium & 7 & Juisticia & 8 & $\begin{array}{l}\text { Asteraceae } \\
\quad \text { (Tubuliflorae) }\end{array}$ \\
\hline 9 & Sapotaceae & 10 & Hygrophila & 11 & Malvaceae & 12 & Apicaceae \\
\hline 13 & Potamogeton & 14 & Trilete fern spore & 15 & Monolete fern spore & 16 & Cheno/Am \\
\hline 17 & Cheno/Am & 18 & Brassicaceae & 19 & Cannabis sativa & 20 & Poaceae \\
\hline 21 & Cerealia & 22 & Cerealia & 23 & Caryophyllaceae & 24 & $\begin{array}{c}\text { Cyperaceae } \\
\text { Type I }\end{array}$ \\
\hline \multirow[t]{2}{*}{25} & $\begin{array}{c}\text { Cyperaceae } \\
\text { Type II }\end{array}$ & 26 & Lemna & 27 & Polygonum serrulatum & 28 & $\begin{array}{c}\text { Zygospores of } \\
\text { Zygnema }\end{array}$ \\
\hline & & & & & & 29 & Botryococcus \\
\hline
\end{tabular}

Note: Magnification: $\times 750$, apart from nos. 6,8 , and $26(\times 1000) ; 21$ and $22(\times 500)$.

ceae (Tubuliflorae and Liguliflorae) and sporadic distribution of other herbaceous plants such as Ranunculaceae, Malvaceae (Hibiscus), Chrozophora, and Justicia. Marshy taxa such as sedges (Cyperaceae), as well as Polygonum, Polygala, Solanum, and Hygrophila, also appeared in high numbers, particularly at Devrajpur (see Fig. 21), the largest reservoir in the area. Also well represented at all three sites were the pollens of aquatic plants such as Lemna, Potamogeton, and Typha (elephant grass); freshwater algae such as Zygnema, Spirogyra and Botryococcus; and monolete and trilete ferns. These pollens all attest to extensive areas of waterlogged, marshy terrain. The predominance of moisture-loving trees such as Madhuca indica (mahua), Syzgium (jamun), Holoptelea (chilbil), and others further supports the picture of a warm, swampy environment. Finally, the limited occurrence of cerealia pollens, along with commonly associated ruderal plants such as Chenopodiaceae/ Amaranthaceae (spinach/amaranth), Caryophyllaceae, Brassicaceae (mustard), and Cannabis sativa (hemp), confirms that much of the surrounding terrain was under cultivation. Unfortunately, these sequences remain undated due to the unsatisfactory nature of the OSL samples from the reservoir cores. This problem will shortly be remedied through a planned program of ${ }^{14} \mathrm{C}$ dating.

\section{CONCLUSION}

The aims of this pilot study were threefold: (1) to assess whether OSL dating is a suitable method for dating the Sanchi dams, in anticipation of a larger-scale project in the future; (2) to carry out preliminary pollen analysis for assessing hypotheses about associated land use; and (3) to clarify issues of dam design by studying sections caused by modern road cuttings. The results have shown that local sediments, as well as methods of dam construction, lend themselves to OSL dating. The most successful samples were S1 and S9 from the Sanchi dam, providing a date range between the third and second centuries B.c. This tallies closely with our principal working hypothesis (Shaw 2004b, forthcoming; Shaw and Sutcliffe 2001, 2003a, 2005) that the Sanchi dams were built around the same time as the earliest Buddhist monuments at Sanchi and neighboring monastic sites, and that, as in Sri Lanka, they were central to the development of exchange networks between monastic and non monastic sections of society. Just as the Sri Lankan evidence has been used to challenge Orientalist- and Marxist-inspired models that attribute the development of complex economies in Asia to centralized state con- 
trol of irrigation resources, so do the intersite patterns at Sanchi attest to similarly devolved systems of water management and patronage in central India based on exchange networks between local landlords, agriculturalists, and religious institutions. Details regarding the possible identity of the local oligarchs who supported the early dam-building programs are given elsewhere, together with the working hypothesis that while this system was initially central to the propagation and institutionalization of Buddhist monasticism, during later periods, the religious monopoly over water and land resources both at Sanchi and across India as a whole was recast within a predominantly Brahmanical framework, in keeping with the gradual demise of Buddhism (Shaw 2004a, forthcoming; Shaw and Sutcliffe 2003a, 2005). ${ }^{31}$

A range of OSL dates between the mid-second and early first millennia B.C. suggests that the building material for the Sanchi dam was sourced from nearby Chalcolithic contexts during the late centuries B.C. The remaining OSL dates, especially from within the reservoir beds at Sanchi and Devjajpur were less instructive. Potential problems may relate to the fact that the sediment was not fully reset by anthropogenic activity or it may have undergone post-depositional disturbance from tree roots resulting in the mixing of younger and older mineral grains. Additional issues which will require further investigation relate to possible dosimetric effects which can only be resolved by in-situ gamma-ray spectrometry measurements. However, the range of preliminary luminescence age estimates is fairly consistent with that expected of Holocene alluvial deposits, confirming further the reliability of the method. Further, although the tendency for alluvial deposits to retain their Holocene time signature meant that the pollen sequences presented here lack a chronological framework, they support the picture of an agricultural landscape interspersed with water bodies and marshland.

Steps toward correcting some of the problems raised here will be central to follow-up research. These will include (1) using a portable gamma spectrometer to measure the effect of the local environment on the annual radiation dose in order to improve OSL dating precision; (2) drilling complete column cores and limited trenches within selected reservoir beds in order to refine current pollen sequences and studying climatic changes over the history of reservoir use; (3) relating pollen sequences to ${ }^{14} \mathrm{C}$-based chronologies; and (4) collecting phytolith samples from associated settlements to identify specific agricultural crops associated with the Sanchi dams.

\section{ACKNOWLEDGMENTS}

We would like to thank Dr. O. P. Misra (Madhya Pradesh Directorate of Archaeology, Archives and Museums, Bhopal) for help with the study of the ceramics from the Sanchi dam; and Emma Harvey (Institute of Archaeology, University College London) for carrying out preliminary analysis of reservoir sediments for their phytolith content and suggesting possible future avenues for phytolith-based research. A British Academy postdoctoral fellowship (Institute of Archaeology, Oxford) and junior research fellowship (Merton College, Oxford) (2002-2005), followed by a lectureship at the Institute of Archaeology, University College London (from 2005), enabled the first author to develop the wider project of which this study forms a component. Grateful thanks go to the British Academy, the Society for South Asian Studies, and Merton College, Oxford, for funding fieldwork; and to the Archaeological Survey of India, Bhopal Circle (particularly S. B. Ota and S. K. Verma) and 
Madhya Pradesh Directorate of Archaeology, Archives and Museums (particularly O. P. Misra) for support and assistance. All figures are by J. Shaw, apart from Figures 19-22 by M. S. Chauhan. Figures 8,17 , and 18 involved the technical input of L. Lloyd-Smith and Figures 5 and 15 that of Anthony Beck (University of Durham). The 2003-2004 field team consisted of the first and third authors, Santosh Kumar Dwivedi (Vidisha), Manoj Kumar Manhi, Sravan Singh Rajput (Sanchi), and Harim, Tariq, Sarman, Sulal, Josef and "W" (Devrajpur). We are grateful to Rahesh Bhai, sarpanch of Devrajpur village for support and hospitality, and to the many villagers, farmers, and landowners whose cooperation and warmth was central to the smooth running of the project. In Lucknow, the help and hospitality of Jaysri Banerji, Indra Goel, and K. S. Saraswat of the Birbal Sahni Institute of Palaeobotany and Rakesh Tewari of the Uttar Pradesh State Archaeology Department are gratefully acknowledged. Thanks to Alexandre G. Mitchell, Helen Lewis, and three anonymous reviewers from Asian Perspectives for reading drafts and offering useful suggestions for improvements. Needless to say, all shortcomings are our own.

\section{NOTES}

Authors' note: The core of this paper was written by the first author, J. Shaw, building on earlier phases of research on the political, economic, and environmental background of Buddhist propagation in central India, much of it published elsewhere (e.g., Shaw 2000, 2004a, 2004b). In particular, the theoretical preamble in "The Sanchi Survey: Background to Research" summarizes more detailed discussions to be found in the first author's forthcoming monograph (Shaw forthcoming). The other authors made the following contributions to the second part of the paper, "The Pilot Project": J. V. Sutcliffe acted as hydrological consultant, drawing on earlier collaborative work (Shaw and Sutcliffe 2001, 2003a, 2003b, 2005); L. Lloyd Smith participated in the 2003-2004 field season and helped in the interpretation of the dam sections and reservoir core sequences; the OSL and TL laboratory analysis was carried out by J.-L. Schwenninger and the pollen analysis by M. S. Chauhan. Contributions by other collaborators are described in the acknowledgements.

1. The pilot project was carried out in January 2004 as a collaboration between the Vidisha Research Group (https://www.britac.ac.uk/institutes/SSAS/groups.vidisha.htm) - formed in 2001 and comprising various subprojects endorsed by the Society for South Asian Studies, including the present study (http://www.britac.ac.uk/institutes/SSAS/projects/sanchi.htm) - and the Madhya Pradesh Directorate of Archaeology, Archives and Museums, Bhopal. It built upon the results of earlier seasons of the Sanchi Survey (Shaw 2000, 2004a, 2004b) first initiated in 1998.

2. Funded by a two-year BASIS grant and involving collaborations between the Vidisha Research Group and Durham University (Anthony Beck), the satellite remote sensing and mapping component of the project sought to develop new reconnaissance strategies and improve the survey's GIS infrastructure. It has also led to the identification of buried palaeochannels associated with the reservoirs (Beck and Shaw forthcoming) and produced evidence of upstream irrigation to support our hypothesis that the dams were built for wet-rice cultivation (Shaw and Sutcliffe 2005). Finally, it has enabled a better understanding of the internal organization and landscape setting of selected Buddhist sites, and thus it has strengthened arguments about the linkages between religion and water management.

3. Preliminary coring was also carried out at Ferozpur, $11 \mathrm{~km}$ to the west of Sanchi. However, no reservoir silts were encountered due to soil erosion caused by high river action.

4. A new project is being developed entitled "Landscapes, Water, and Religion in Ancient India," which will include similar methodological approaches to selected dams in Gujarat and Maharashtra (http://www.britac.ac.uk/institutes/SSAS/projects/sanchi.htm).

5. The Sanchi Survey was partly aimed at redressing this problem (see Shaw forthcoming).

6. This view has been challenged in recent years, the current understanding being that the edicts mark the farthest extent of Mauryan interaction with neighboring polities (Fussman 1988; Sugandhi 2003).

7. This treatise on state organization is purported to have been authored by the minister of Candragupta Maurya (326-313 B.C.). Despite the reluctance of many scholars to acknowledge its anachronistic qualities, it is now thought to be a much later text, probably not reaching its final form until the third century A.D. or later (Trautmann 1971).

8. Exceptions include the early Chola dams in South India (Venkayya 1906) and the Sudarśana dam in Junagadh, Gujarat (Mehta 1968). The latter has provided a useful comparative framework for the Sanchi dams (Shaw and Sutcliffe 2003a). 
9. These figures are slightly higher than previous calculations (Shaw and Sutcliffe 2001, 2003a, $2003 \mathrm{~b}$ ), following estimates based on high-resolution mapping and satellite remote sensing.

10. Nāgas, traditionally associated with fertility, are found throughout South Asia close to bodies of water. Their spatial and temporal distribution in the Sanchi area sheds important light on theories of religious change, especially with regard to the dynamics between Buddhism and "local" agricultural cults. Gupta-period accounts of Chinese pilgrims in eastern India show that nāga shrines were propitiated by monks, often within monastic settings, because of the nāgas' perceived ability to regulate rainfall and agricultural productivity. The positioning of nāga shrines on or near the Sanchi dams conforms to this model and supports the hypothesis presented elsewhere (Shaw 2004a; Shaw and Sutcliffe 2003a) that năga worship was part of Buddhist practice because its effects were in keeping with the saigha's economic concerns, including water harvesting and agrarian production.

11. Grateful thanks to Norman Hammond for this reference.

12. OSL refers to the levels of luminescence (light) emitted on exposure to light as the result of released energy accumulated in crystalline materials through the action of ionizing radiation from natural radioactivity. When a sediment is exposed to sunlight prior to deposition, the OSL acquired over geological time is removed; the luminescence clock is thus set to zero. The OSL then accumulates in response to the ionizing radiation received during the burial period of the sediment. The level of OSL observed in ancient samples is thus dependent on the absorbed radiation dose, and hence it can be related to the time elapsed since last illumination/heating once the dose received per year (during burial) has been calculated (http://www.rlaha.ox.ac.uk/ lumin/lumindx.html).

13. A useful avenue for future research would be to use this figure to estimate total possible rice yields across the area and the impact that such levels may have had on population densities as suggested by monastery and settlement distribution.

14. The most reliable dates are from Damadama (Fuller 2002, 2003) and more recently Lahuradewa (Fuller in press); earlier dates in the fifth and fourth millennia B.C. have been suggested for Koldihawa and Chopani Mando, respectively (Sharma et al. 1980), although these are no longer considered reliable.

15. Despite reported rice finds from Chalcolithic sites in northern Maharashtra and the Narmada valley (Dhavalikar 1985), neither sample quantity nor collection strategy justifies viewing rice as having played a significant role in subsistence patterns (Fuller 2002).

16. References in early Buddhist texts show that rice was not only central to the Gangetic valley diet, but that it was also important in ritual and medicinal practice (Shaw and Sutcliffe 2003a, 2005). Analogies with the relationship between the spread of Islam and the introduction of new crops (including rice and sugarcane) to the Middle East and the Mediterranean are discussed in Shaw 2005.

17. Grateful thanks to Emma Harvey for carrying out this preliminary work and for giving advice over future phytolith-based research in the Sanchi area.

18. Earlier uncertainties over the function of the second dam due to the higher ground levels to the south were clarified by recent contour planning (Shaw and Sutcliffe 2003a, 2005). The dam's position outside the basin's natural drainage channel suggests that it acted as a retaining wall rather than a storage dam.

19. This is a common practice in many parts of Madhya Pradesh today (Agarwal et al. 2003:19, 27).

20. Included in this pile of dislodged slabs is a dressed corner stone covered with chisel marks (Fig. 9), which was probably intended for architectural purposes elsewhere. This probably originated from the quarrying and stone cutting center on Nagauri hill, which provided the building material for many of Sanchi's Buddhist monuments.

21. SF 2, 3, 5, and 6.

22. Grateful thanks to O. P. Misra for help in studying this material.

23. The fact that it also marks the center of the dam and is found so close to the adjoining hill where one may assume the construction of the dam began raises the obvious question of whether we are dealing with some kind of consecratory deposit. However, although its upright position and location are very suggestive, it is unlikely that a broken vessel would have been used for ritual purposes. An alternative suggestion is that it was found in a spoil heap along with the rest of the dam construction material and that, due to its distinctive shape and semicomplete condition, it was-on a whimsical decision-given a prominent position at the center of the dam.

24. Its gray color could relate to degraded iron, typical of waterlogged deposits (Helen Lewis, pers. comm.).

25. A minimum heat of $350^{\circ} \mathrm{C}$ is required for the OSL clock to be reset to zero.

26. For this reason, reanalysis was carried out, which involved soaking the samples in acid over several weeks. The new results are still awaited. 
27. Unfortunately, however, there has been an increase in the removal of stone facing blocks for commercial purposes.

28. Devrajpur village sarpanch, Sri Rahesh Bhai, pers. comm. (Jan. 2004). The term "sisiśa" may be a reference to the mortar's high lime content.

29. More precise dating would require the use of a portable gamma spectrometer to measure the annual dose of radiation in the stone slabs as well as the surrounding soil matrix.

30. According to locals, this area remains waterlogged long after the monsoon and is thus planted with more moisture-dependent crops.

31. For the impact of the decline of Buddhism on the later history of the Sanchi dams in the second half of the first millennium A.D., see Shaw forthcoming; Shaw and Sutcliffe 2003a, 2005.

\section{REFERENCES}

Agarwal, A., S. Narain, and I. Khurana

2003 Making Water Everybody's Business: Practice and Policy of Water Harvesting. New Delhi: Centre for Science and Environment.

Allchin, F. R., and K. R. Norman

1985 Guide to the Aśokan inscriptions. South Asian Studies 1:43-50.

Bailey, G., AND I. MabBett

2003 The Sociology of Early Buddhism. Cambridge: Cambridge University Press.

Ball, T., J. D. Brotherson, and J. S. Gardner

1993 A typologic and morphometric study of variation in phytoliths from einkorn wheat (Triticum monococcum). Canadian Journal of Botany 71:1182-1192.

BECHERT, H., ED.

1991 The Dating of the Historical Buddha. Göttingen: Vandenhoeck \& Ruprecht.

BeCK, A. AND J. SHAw

Forth- The archaeological application of satellite remote-sensing in the Sanchi area, Madhya coming Pradesh, India.

Bishop, P., D.C.W. SANDerson, AND M. T. Stark

2004 OSL and radiocarbon dating of a pre-Angkorian canal in Mekong delta, southern Cambodia. Journal of Archaeological Science 31:319-336.

Brohier, R. L.

1979 Ancient Irrigation Works in Ceylon. Reprint of 1934 ed. Colombo, Sri Lanka: Ministry of Mahaweli Development.

Chakravarty, $\mathrm{R}$.

1998 The creation and expansion of settlements and management of hydraulic resources in ancient India, in Nature and the Orient: The Environmental History of South and Southeast Asia: 87-106, ed. R. Grove, H. V. Damodaran, and S. Sangwan. New Delhi: Oxford University Press.

Chauhan, M. S.

1996 Origin and history of tropical deciduous sal (Shorea Robusta Gaernt.) forests in Madhya Pradesh, India. Palaeobotanist 43:89-101.

2000 Pollen evidence of late-Quaternary vegetation and climate change in northeastern Madhya Pradesh. Palaeobotanist 49:491-500.

2002 Holocene vegetation and climatic changes in southeastern Madhya Pradesh, India. Current Science 83(12): 1444-1445.

Coningham, R.

2001 The archaeology of Buddhism, in Archaeology and World Religion: 60-95, ed. T. Insoll. London: Routledge.

Cunningham, A.

1854 The Bhilsa Topes. London: Smith, Elder and Co.

Davison-Jenkins, D. J.

1997 The Irrigation and Water Supply Systems of Vijayanāgara. New Delhi: Manohar, American Institute of Indian Studies. 
DeHeJiA, V.

1992 Collective and popular bases of early Buddhist patronage: Sacred monuments, 100 B.C.A.D. 250, in The Powers of Art: Patronage in Indian Culture: 35-46, ed. B. Stoler-Miller. Delhi: Oxford University Press.

Dhavalikar, M. K.

1985 Cultural ecology of Chalcolithic Maharashtra, in Recent Advances in Indian Archaeology: 65-73, ed. S. B. Deo and K. Paddayya. Poona: Deccan College.

Eksambekar, S. P., S. R. Sainkar, and M. D. Kajale

1999 Phytolith study using scanning electron microscope (SEM): Some initial considerations. Bulletin of the Deccan College Post-Graduate Research Institute 58:85-92.

ERdTMAN, G.

1943 An Introduction to Pollen Analysis. Waltham, MA: Chronica Botanica.

Fujiwara, H., M. R. Mughal, A. Sasaki, and T. Matano

1992 Rice and ragi at Harappa: Preliminary results by plant opal analysis. Pakistan Archaeology $27: 129-142$

Fuller, D. Q.

2002 Fifty years of archaeobotanical studies in India: Laying a solid foundation, in Indian Archaeology in Retrospect, vol. 3: Archaeology and Interactive Disciplines: 247-363, ed. S. Settar and R. Korisettar. New Delhi: Manohar.

2003 Indus and non-Indus agricultural traditions: Local developments and crop adoptions on the Indian Peninsula, in Indus Ethnobiology: New Perspectives from the Field: 343-395, ed. S. A. Weber and W. R. Belcher. New York and Oxford: Lexington Books.

In press The Ganges on the world Neolithic map: The significance of recent research on agricultural origins in northern India. Pragdhara (Journal of the Uttar Pradesh State Department of Archaeology).

Fussman, G.

1988 Central and provincial administration in ancient India: The problem of the Mauryan Empire. The Indian Historical Review 14:41-72.

Geertz, C.

1980 Negara: The Theatre State in Nineteenth-Century Bali. Princeton: Princeton University Press.

Gunawardana, R.A.H.L.

1971 Irrigation and hydraulic society in early medieval Ceylon. Past and Present 53:3-27.

1979 Robe and Plough: Monasticism and Economic Interest in Early Medieval Sri Lanka. Tucson: Association for Asian Studies, University of Arizona Press.

Harvey, E. L., D. Q. Fuller, J. N. Pal, and M. C. Gupta

2005 Early agriculture of the Neolithic Vindhyas (North-Central India), in South Asian Archaeology: Proceedings of the European Association for South Asian Archaeology Conference, Bonn, Germany, 7th-11th July 2003: 329-334, ed. U. Franke-Vogt and H.-J. Weisshaar. Aachen: Linden Soft.

Hodnett, M. G., And J. P. Bell

1986 Soil moisture investigations of groundwater recharge through black cotton soils in Madhya Pradesh, India. Hydrological Sciences Journal 31(3):361-381.

Houyuan, L., W. Naiqin, AND L. BaOzhu

1997 Recognition of rice phytoliths, in The First European Meeting on Phytolith Research: The State of the Art of Phytoliths in Soils and Plants: 159-174, ed. A. Pinilla, J. Juan-Tresserras, and M. J. Machado. Madrid: Centro de Ciencias Medioambiantales, Consejo Superior de Investigaciones Cientificas.

Kajale, M. D., and S. P. Eksambekar

2001 Phytolith approach for investigating ancient occupations at Balathal, Rajasthan, India. Part 1: Evidence of crops exploited by initial farmers, in Phytoliths: Applications in Earth Sciences and Human History: 199-204, ed. J. D. Meunier and F. Colin. Abingdon, UK: A. A. Balkema.

LANSING, J.

1991 Priests and Programmers: Technologies of Power in the Engineered Landscape of Bali. Princeton, NJ: Princeton University Press. 
LEACH, E. R.

1959 Hydraulic society in Ceylon. Past and Present 15:2-26.

Madella, M.

2003 Investigating agriculture and environment in South Asia: Present and future contributions from opal phytoliths, in Indus Ethnobiology: New Perspectives from the Field: 199-249, ed. S. Weber and W. R. Belcher. Lanham, MD: Lexington Books.

Marshall, J. H.

1918 A Guide to Sanchi. Calcutta: Superintendent Government Printing.

Marshall, J. H., A. Foucher, and N. G. Majumdar

1940 The Monuments of Sanchi. Calcutta: Survey of India Offices Heliozincograph.

Menta, R. N.

1968 Sudarsana lake. Journal of Oriental Institute, MS University Baroda 18:18-28.

MORrison, K.

1993 Supplying the city: The role of reservoirs in the Indian urban landscape. Asian Perspectives $32(2): 133-149$.

Myrdal-RunebJer, E.

1994 Vavala vava-Sigiri Mahavava irrigation system: Preliminary results from an archaeological case study, in South Asian Archaeology 1993: 551-562, ed. A. Parpola and P. Koskikallio. Helsinki: Suomalainen Tiedeakatemia.

PARKER, H.

1909 Ancient Ceylon: An Account of the Aborigines and of Part of the Early Civilisation. London: Luzac \& Co.

Risberg, J., E. Myrdal-Runebjer, And U. Miller

2002 Sediment and soil characteristics and an evaluation of their applicability to the irrigation history in Sigiriya, Sri Lanka. Journal of Nordic Archaeological Science 13:27-42.

Rosen, A. M.

1992 Preliminary identification of silica skeletons from Near Eastern archaeological sites: An anatomical approach, in Phytolith Systematics: Emerging Issues: 129-147, ed. G. Rapp Jr. and S. C. Mulholland. New York: Plenum.

SCHOPEN, G.

1996 What's in a name: The religious function of early donative inscriptions, in Unseen Presence: The Buddha and Sanchi: 58-73, ed. V. Dehejia. Mumbai: Marg Publications.

Sharma, G. R., V. D. Misra, D. Mandal, et al.

1980 Beginnings of Agriculture (Epi-Palaeolithic to Neolithic): Excavations at Chopani-Mando, Mahadaha and Mahagara. Allahabad, India: Abinash Prakshan.

Sharma, R. K., and O. P. Misra

2003 Archaeological Excavations in Central India (Madhya Pradesh and Chhattisgarh). New Delhi: Mittal Publications.

SHAW, J.

2000 Sanchi and its archaeological landscape: Buddhist monasteries, settlements and irrigation works in central India. Antiquity $74: 775-776$.

2004a Nāga sculptures in Sanchi's archaeological landscape: Buddhism, Vaisnavism and local agricultural cults in central India, first century BCE to fifth century CE. Artibus Asiae 64(1): 5-59.

2004b Early historic landscapes in central India: Recent archaeological investigations in districts Raisen and Vidisha, Madhya Pradesh, 2003-4. Journal of Interdisciplinary Studies in History and Archaeology 1:143-150.

2005 The archaeological setting of Buddhist monasteries in central India: A summary of a multi-phase survey in the Sanchi area, 1998-2000, in South Asian Archaeology: Proceedings of the Sixteenth International Conference of the European Association of South Asian Archaeologists: 665-676, ed. C. Jarrige and V. Lefèvre. Paris: Éditions Recherche sur les Civilisations, ADPF.

Forth- Buddhist Landscapes in Central India: Sanchi Hill and Archaeologies of Religious and Social coming Change, c. 3rd century BC to 5th century AD. London: UCL Press.

Shaw, J., AND M. S. Chauhan

Forth- Palaeovegetation and palaeoclimatic studies from Raisen/Vidisha Districts, Madhya Pracoming desh, based on pollen evidence. 
Shaw, J., AND J. V. Sutcliffe

2001 Ancient irrigation works in the Sanchi area: An archaeological and hydrological investigation. South Asian Studies 17:55-75.

2003a Water management, patronage networks and religious change: New evidence from the Sanchi dam complex and counterparts in Gujarat and Sri Lanka. South Asian Studies 19:73-104.

2003b Ancient dams, settlement archaeology and Buddhist propagation in central India: The hydrological background. Hydrological Sciences Journal 48(2): 277-291.

2005 Ancient dams and Buddhist landscapes in the Sanchi area: New evidence for irrigation, land-use, and monasticism in central India. South Asian Studies 21:1-24.

Sugandhi, N.

2003 Context, content, and composition: Questions of intended meaning and the Aśokan edicts. Asian Perspectives 42(2): 224-246.

Trautmann, T.

1971 Kautilya and the Arthasastra: A Statistical Investigation of the Authorship and Evolution of the Text. Leiden: Brill.

VENKAYYA, V.

1906 Irrigation in South India in ancient times. Archaeological Survey of India Annual Report 1903-1904: 202-211.

WILLIS, M.

2000 Buddhist Reliquaries from Ancient India. With contributions by J. Cribb and J. Shaw. London: British Museum Press.

WitTFOgeL, K. A.

1957 Oriental Despotism: A Comparative Study of Total Power. New Haven: Yale University Press.

\section{ABSTRACT}

This paper presents the results of a recent pilot project aimed at obtaining optically stimulated luminescence (OSL) dates from a group of ancient irrigation dams in central India. The dams are all situated within an area of $750 \mathrm{~km}^{2}$ around the wellknown Buddhist site of Sanchi, the latter established in c. third century B.C. and having a continuous constructional sequence up to the twelfth century A.D. They were documented during earlier seasons of the Sanchi Survey, initiated in 1998 in order to relate the site to its wider archaeological landscape. The pilot project builds upon earlier hypotheses regarding the chronology and function of the Sanchi dams and their relationship to religious and political history in Central India. The principal suggestion is that the earliest phase of dam construction coincided with the rise of urbanization and the establishment of Buddhism in central India between c. third and second centuries B.C.; and that they were connected with wet-rice cultivation as opposed to wheat, the main agricultural staple today. Similarities with intersite patterns in Sri Lanka, where monastic landlordism is attested from c. second century B.C. onward, have also led to the working hypothesis that the Sanchi dams were central to the development of exchange systems between Buddhist monks and local agricultural communities. The pilot project focused on two out of a total of $16 \mathrm{dam}$ sites in the Sanchi area and involved scraping back dam sections created by modern road cuttings. This cast new light on aspects of dam construction and allowed for the collection of sediments and ceramics for OSL dating. The results confirmed the suitability of local sediments to OSL dating methods, as well as affirming our working hypothesis that the dams were constructed-along with the earliest Buddhist monuments in Central India-in the late centuries B.C. Sediment samples were also collected from cores hand drilled in the dried-up reservoir beds, for supplementary OSL dating and pollen analysis, which shed useful insights into land use. KEYWORDS: irrigation, dams, rice agriculture, OSL dating, pollen analysis, ancient India, spread of Buddhism, religious change, theories of state. 